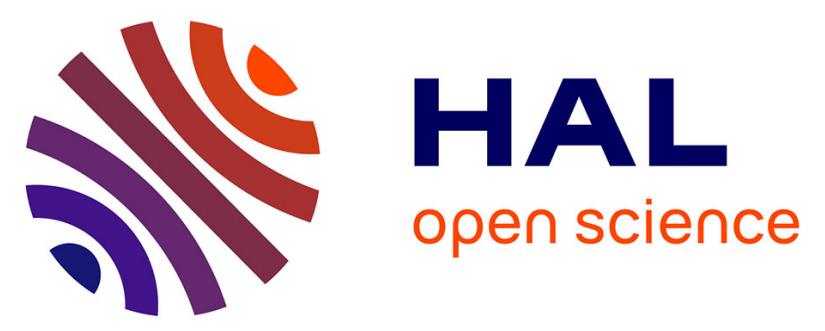

\title{
First report of a bothremydid turtle, Sindhochelys ragei n. gen., n. sp., from the early Paleocene of Pakistan, systematic and palaeobiogeographic implications
}

France de Lapparent de Broin, Grégoire Métais, Annachiara Bartolini, Imdad Ali Brohi, Rafiq A. Lashari, Laurent Marivaux, Didier Merle, Mashooque Ali Warar, Sarfraz H. Solangi

\section{To cite this version:}

France de Lapparent de Broin, Grégoire Métais, Annachiara Bartolini, Imdad Ali Brohi, Rafiq A. Lashari, et al.. First report of a bothremydid turtle, Sindhochelys ragei n. gen., n. sp., from the early Paleocene of Pakistan, systematic and palaeobiogeographic implications. Geodiversitas, 2021, Memorial Jean-Claude Rage: A life of paleo-herpetologist, 43 (25), pp.1341-1363. 10.5252/geodiversitas2021v43a25 . hal-03475720

\section{HAL Id: hal-03475720 \\ https://hal.umontpellier.fr/hal-03475720}

Submitted on 11 Dec 2021

HAL is a multi-disciplinary open access archive for the deposit and dissemination of scientific research documents, whether they are published or not. The documents may come from teaching and research institutions in France or abroad, or from public or private research centers.
L'archive ouverte pluridisciplinaire HAL, est destinée au dépôt et à la diffusion de documents scientifiques de niveau recherche, publiés ou non, émanant des établissements d'enseignement et de recherche français ou étrangers, des laboratoires publics ou privés. 


\section{geodiversitas $2021 \cdot 43 \cdot 25$}

First report of a bothremydid turtle, Sindhochelys ragei n. gen., n. sp., from the early Paleocene of Pakistan, systematic

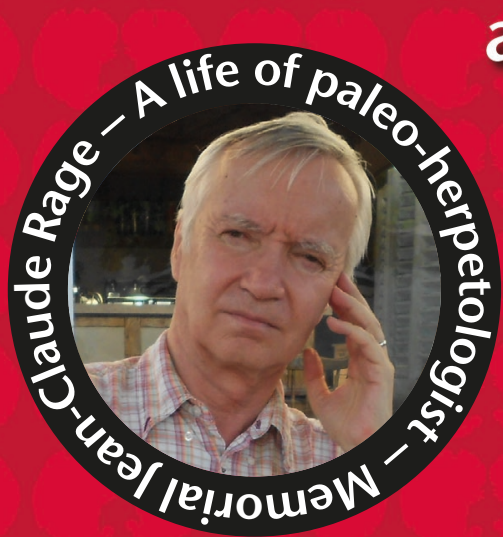

France de LAPPARENT DE BROIN, Grégoire METAIS, Annachiara BARTOLINI, Imdad Ali BROHI, Rafiq A. LASHARI, Laurent MARIVAUX, Didier MERLE, Mashooque Ali WARAR \& Sarfraz H. SOLANGI
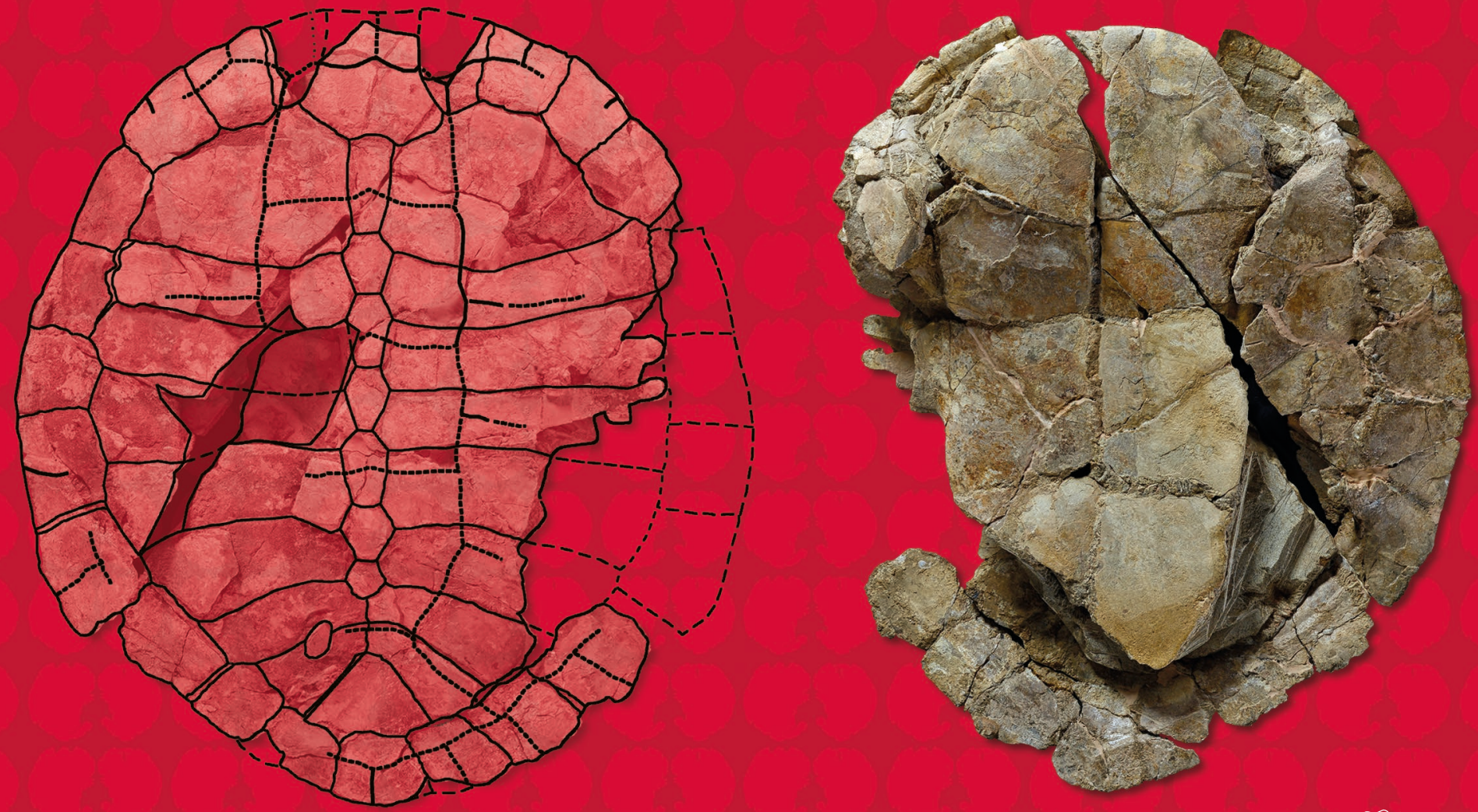

art. 43 (25) - Published on 9 December 2021 
DiReCteur de LA PUblication / PUBLICATION DIRECTOR : Bruno David,

Président du Muséum national d'Histoire naturelle

RÉDACTEUR EN CHEF / EDITOR-IN-CHIEF: Didier Merle

ASSISTANT DE RÉDACTION / ASSISTANT EDITOR: Emmanuel Côtez (geodiv@mnhn.fr)

Mise EN PAGE / PAGE LAYOUT: Emmanuel Côtez

COMITÉ SCIENTIFIQUE / SCIENTIFIC BOARD:

Christine Argot (Muséum national d'Histoire naturelle, Paris)

Beatrix Azanza (Museo Nacional de Ciencias Naturales, Madrid)

Raymond L. Bernor (Howard University, Washington DC)

Alain Blieck (chercheur CNRS retraité, Haubourdin)

Henning Blom (Uppsala University)

Jean Broutin (Sorbonne Université, Paris, retraité)

Gaël Clément (Muséum national d'Histoire naturelle, Paris)

Ted Daeschler (Academy of Natural Sciences, Philadelphie)

Bruno David (Muséum national d'Histoire naturelle, Paris)

Gregory D. Edgecombe (The Natural History Museum, Londres)

Ursula Göhlich (Natural History Museum Vienna)

Jin Meng (American Museum of Natural History, New York)

Brigitte Meyer-Berthaud (CIRAD, Montpellier)

Zhu Min (Chinese Academy of Sciences, Pékin)

Isabelle Rouget (Muséum national d'Histoire naturelle, Paris)

Sevket Sen (Muséum national d'Histoire naturelle, Paris, retraité)

Stanislav Štamberg (Museum of Eastern Bohemia, Hradec Králové)

Paul Taylor (The Natural History Museum, Londres, retraité)

COUVERTURE / COVER:

Réalisée à partir des Figures de l'article/Made from the Figures of the article.

Geodiversitas est indexé dans / Geodiversitas is indexed in:

- Science Citation Index Expanded (SciSearch ${ }^{\circledR}$ )

- ISI Alerting Services ${ }^{\circledR}$

- Current Contents ${ }^{\circledR}$ / Physical, Chemical, and Earth Sciences ${ }^{\circledR}$

- Scopus ${ }^{\circledR}$

Geodiversitas est distribué en version électronique par / Geodiversitas is distributed electronically by:

- BioOne ${ }^{\circledR}$ (http://www.bioone.org)

Les articles ainsi que les nouveautés nomenclaturales publiés dans Geodiversitas sont référencés par / Articles and nomenclatural novelties published in Geodiversitas are referenced by:

- ZooBank ${ }^{\circledR}$ (http://zoobank.org)

Geodiversitas est une revue en flux continu publiée par les Publications scientifiques du Muséum, Paris Geodiversitas is a fast track journal published by the Museum Science Press, Paris

Les Publications scientifiques du Muséum publient aussi / The Museum Science Press also publish: Adansonia, Zoosystema, Anthropozoologica, European Journal of Taxonomy, Naturae, Cryptogamie sous-sections Algologie, Bryologie, Mycologie, Comptes Rendus Palevol

Diffusion - Publications scientifiques Muséum national d'Histoire naturelle

CP $41-57$ rue Cuvier F-75231 Paris cedex 05 (France)

Tél. : 33 (0)1 40794805 / Fax: 33 (0)14079 3840

diff.pub@mnhn.fr / http://sciencepress.mnhn.fr

(C) Publications scientifiques du Muséum national d'Histoire naturelle, Paris, 2021

ISSN (imprimé / print): 1280-9659/ ISSN (électronique / electronic): 1638-9395 


\section{First report of a bothremydid turtle, Sindhochelys ragei n. gen., n. sp., from the early Paleocene of Pakistan, systematic and palaeobiogeographic implications}

France de LAPPARENT DE BROIN

Grégoire MÉTAIS

Annachiara BARTOLINI

Centre de Recherches sur la Paléobiodiversité et les Paléoenvironnements,

CR2P (CNRS, MNHN, UPMC, Sorbonne Université),

Département Origines et Évolution, Muséum national d'Histoire naturelle, case postale 38, 57 rue Cuvier, F-75231 Paris cedex 05 (France)

gregoire.metais@mnhn.fr (corresponding author)

france.delapparent123@orange.fr (corresponding author)

Imdad Ali BROHI

Centre for Pure and Applied Geology, University of Sindh, Allama I. I. Kazi Campus, Jamshoro 76080 (Pakistan)

Rafiq A. LASHARI

Centre de Recherches sur la Paléobiodiversité et les Paléoenvironnements, CR2P (CNRS, MNHN, UPMC, Sorbonne Université),

Département Origines et Évolution, Muséum national d'Histoire naturelle, case postale 38, 57 rue Cuvier, F-75231 Paris cedex 05 (France) and Centre for Pure and Applied Geology, University of Sindh, Allama I.I. Kazi Campus, Jamshoro 76080 (Pakistan)

Laurent MARIVAUX Laboratoire de Paléontologie, Institut des Sciences de l'Évolution de Montpellier (ISE-M), UMR 5554 CNRS/UM/IRD/EPHE, cc 064, Université de Montpellier (UM), place Eugène Bataillon, F-34095 Montpellier cedex 5 (France)

Didier MERLE Centre de Recherches sur la Paléobiodiversité et les Paléoenvironnements, CR2P (CNRS, MNHN, UPMC, Sorbonne Université), Département Origines et Évolution, Muséum national d'Histoire naturelle, case postale 38, 57 rue Cuvier, F-75231 Paris cedex 05 (France)

Mashooque Ali WARAR

Sarfraz H. SOLANGI

Centre for Pure and Applied Geology, University of Sindh, Allama I.I. Kazi Campus, Jamshoro 76080 (Pakistan)

Lapparent de Broin F. de, Métais G., Bartolini A., Brohi I. A., Lashari R. A., Marivaux L., Merle D., Warar M. A. \& Solangi S. H. 2021. - First report of a bothremydid turtle, Sindhochelys ragei n. gen., n. sp., from the early Paleocene of Pakistan, systematic and palaeobiogeographic implications, in Steyer J.-S., Augé M. L. \& Métais G. (eds), Memorial Jean-Claude Rage: A life of paleo-herpetologist. Geodiversitas 43 (25): 1341-1363. https://doi.org/10.5252/geodiversitas2021v43a25. http://geodiversitas.com/43/25 
KEY WORDS

Bothremydidae, Southern Pakistan, geology,

Pelomedusoides, Gondwana,

Neotethys, new genus, new species.

MOTS CLÉS

Bothremydidae,

Sud Pakistan, géologie,

Pelomedusoides,

Gondwana,

Néotéthys,

genre nouveau,

espèce nouvelle.

\begin{abstract}
We report the discovery of remains of a large chelonian from the base of the early Paleocene Khadro Formation exposed in the Ranikot Fort area (Ranikot Group, Sindh Province, Southern Pakistan). This formation already yielded the snake Gigantophis Andrews, 1901, studied by our friend Jean-Claude Rage. The chelonian specimens consist of a large carapace and a shell fragment of Bothremydidae, a family of Gondwanan origin. A new genus and species, Sindhochelys ragei n. gen., n. sp. is identified from the first specimen and named in honor of Jean-Claude Rage. It is the first report of a Bothremydidae in Southern Pakistan. Its affinities with Cretaceous and Paleocene representatives of the family are discussed. The association of characters such as the shape of the shell, anterior plastral scute pattern and strongly marked decoration characterize the taxon and, despite some similarities, allows excluding close phylogenetic affinities with Taphrosphyini and Carteremys group; other welldocumented bothremydids are also excluded. The shell fragment, also strongly decorated, is left undetermined. The discovery of two new littoral bothremydid specimens in the early Paleocene of Pakistan fills a geographic and stratigraphic gap in our knowledge of the family, which is known since the continental early Cretaceous of Africa, diversifying in the world up to the Miocene deposits of the Neotethys. A particular diversification during the Maastrichtian-Paleocene is recognized along the neotethyan coasts, and occasional dispersals across this ocean were possible. Sindhochelys ragei n. gen., n. sp. may have colonized the Indian subcontinent by this time, or may represent an older diversification before the Gondwana breakup.
\end{abstract}

\section{RÉSUMÉ}

Première mention d'une tortue bothrémydidée, Sindhochelys ragei $n$. gen., n. sp., du Paléocène inférieur du Pakistan, implications systématiques et paléobiogéographiques.

Nous présentons la découverte de restes de grand chélonien provenant de la base du Paléocène inférieur de la Formation Khadro, affleurant dans la région du Fort Ranikot (Groupe Ranikot, Province du Sindh, Sud du Pakistan). Cette formation a déjà livré le serpent Gigantophis Andrews, 1901 étudié par notre ami Jean-Claude Rage. Deux spécimens, une carapace et un autre fragment de tortue Bothremydidae, famille d'origine gondwanienne, sont décrits. Un nouveau genre Sindhochelys ragei n. gen., n. sp. est nommé en l'honneur de Jean-Claude Rage. C'est la première découverte d'un bothrémydidé dans le sud-ouest du Pakistan. Les relations avec les représentants crétacés et paléocènes de la famille sont examinées. L'association de caractères comme la forme de la carapace, le pattern des écailles plastrales antérieures et la décoration très accusée le caractérisent et, malgré des similitudes, exclut toute affinité avec les Taphrosphyini et le groupe indien Carteremys, les autres bothrémydidés bien définis étant aussi exclus. L'autre fragment, également très décoré, reste indéterminé. La découverte de ces deux spécimens dans un environnement littoral du Paléocène inférieur du Pakistan comble une lacune géographique et stratigraphique dans la connaissance des Bothremydidae, connus depuis le Crétacé inférieur continental d'Afrique et s'étant répartis dans le monde jusqu'au Miocène de la Néotéthys. Une importante diversification est reconnue pendant le Maastrichtien et le Paléocène, avec une dispersion le long des côtes néotéthysienne et peut-être à travers cet océan: Sindhochelys ragei n. gen., n. sp. peut avoir colonisé le sous-continent Indien à cette époque, ou résulter d'une ancienne diversification avant la rupture du Gondwana.

\section{INTRODUCTION}

Bothremydidae is a clade of extinct turtles known from the Cretaceous to Paleogene of African plate, Europe, India, Madagascar, and North and South America. The first record of this group extends back to the early Cretaceous of continental South America and Africa. They represent a monophyletic family of pleurodiran turtles, belonging to the higher group of Pelomedusoides Podocnemidoidea. The family is the sister taxon of the Podocnemididae (Broin in Antunes \& Broin 1988; Gaffney et al. 2006). Bothremydidae originated on the Gondwana, when Africa, Madagascar, India (including Pakistan) and South America (Brazil) were linked. The oldest representatives of the bothremydids are Cearachelys Gaffney,
Campos de Almeida \& Hirayama, 2001 from the late Albian of the Chapada do Araripe (Brazil), Galianemys Gaffney, Tong \& Meylan, 2002 from the late Albian-early Cenomanian of the Hamada du Guir (Kem Kem beds, Morocco) in the upper part of the "Continental Intercalaire supérieur Saharien" (Upper Intercalary Continental of Sahara), and probably the poorly known taxon "Eusarkia sp." Bergounioux \& Crouzel, 1968, from Tikarkas (Mali) where is recorded the same Albian-early Cenomanian "Continental Intercalaire". Across Sahara, these terrestrial clastics are generally capped by marine beds deposited during the Cenomano-Turonian transgression.

During the Barremian-early Aptian, the family was possibly present in Niger and Brazil where undetermined turtle remains have been reported (Campos de Almeida \& Broin 1981). 
A

A $\quad 67^{\circ} 50^{\prime}$

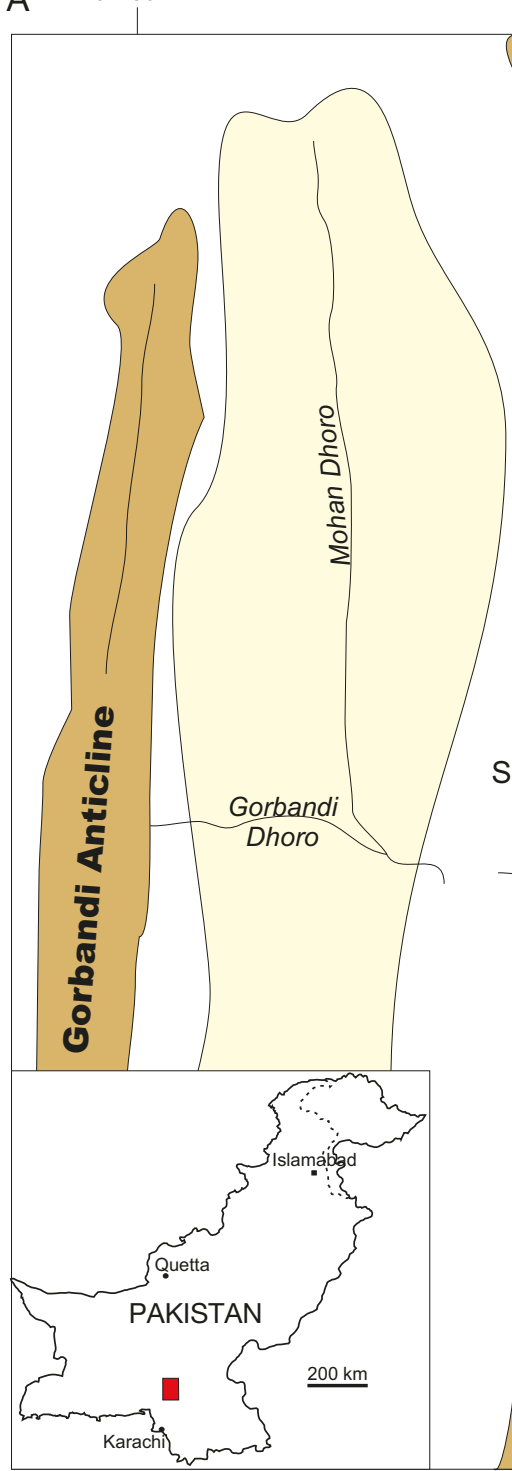

$67^{\circ} 55^{\prime}$

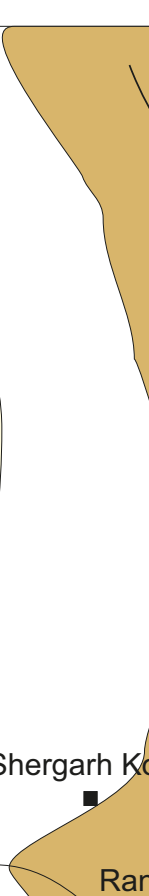

$26^{\circ} 00^{\prime} \mathrm{N}$

B 
TABLE 1. - Sindhochelys ragei n. gen., n. sp., holotype CPAG-RANKT-V-3, from the Paleocene of Ranikot, locality K18-12, Southern Pakistan. Shell measurements are in $\mathrm{cm}$.

\begin{tabular}{lc}
\hline Body part & Shell measurements \\
\hline Carapace length - preserved & 69.5 \\
Carapace length - estimated & 70 \\
Carapace length along curve & 72 \\
Carapace width - maximal preserved at & 54.5 \\
$\quad$ peripherals 5/6 junction & 61 \\
Carapace width - estimated & 16.5 and 17 \\
Costal 1, maximal length, left and right & 13 and 11.5 \\
Costal 1, maximal width, left and right & 54.7 \\
Plastron, full preserved length & c. 57 \\
Plastron, full estimted length & c. 20.5 \\
Bridge length & 15 \\
Anterior lobe length up to axillary notch & c. $28-29$ \\
Anterior lobe width at axillary notch & c. $22-23$ \\
Posterior lobe length up to inguinal notch & 27 \\
Posterior lobe width at abdominofemoral & \\
$\quad$ sulcus end in inguinal notch & 7.5 and 8 \\
Entoplastron, length and width & 1.7 \\
Epiplastral sympysis length & 8.7 and 9.8 \\
Mesoplastron, left, length and width &
\end{tabular}

Moreover, Broin (1980) reported shells of various individuals from the unit 5 of the Elrhaz Formation in Gadoufaoua, Niger (Taquet 1976), which were attributed to the continental freshwater turtle Platycheloides cf. nyasae Haughton 1928, a form known from the Cretaceous of Malawi. However, the material from Niger was recognized as clearly distinctive from P. nyasae, as noted with M. Cooper (Bulawayo, Zimbabwe) (Lapparent de Broin 2000), and it has been renamed Francemys gadoufaoudensis by Pérez-García (2019a). The latter taxon from Gadoufaoua is a Pelomedusoides showing many primitive features and few derived features, such as a marked fine polygonal decoration and the low shell shape with rounded peripheral border, shared with the Bothremydidae. During the Cenomanian, the continental bothremydids became littoral turtles, and widely spread along the coasts of the western Tethys-Atlantic, between Africa, Middle East and Europe, being notably known during the Cenomanian of Palestine and Portugal (Haas 1978a, b; Pérez-García 2016, 2018a; Pérez-García et al. 2017a) and up to North America (Joyce et al. 2016). They had extensively diversified since the Senonian-Maastrichtian times until their last representatives documented in the Miocene of Oman (Broin 1988; Broin in Antunes \& Broin 1988; Roger et al. 1994; Lapparent de Broin \& Werner 1998; Lapparent de Broin 2000, 2001; Gaffney et al. 2006; Lapparent de Broin et al. 2018 [online supplementary data]; Lapparent de Broin \& Guntupalli 2020). Outside Africa-South America in other Gondwanan continents, the oldest bothremydid is an unnamed taxon from the early Albian-middle Turonian Karai Formation of southeastern India (Ayyasami \& Das 1990; Lapparent de Broin \& Guntupalli 2020). The family is well documented in the Maastrichtian infratrappean and intertrappean beds of the Deccan volcanic province of India (Carter 1852, Williams 1953; Jain 1977, 1986; Gaffney et al. 2001b, 2003, 2006; Lapparent de Broin \& Guntupalli 2020) and in Madagascar (Gaffney et al. 2006; Gaffney \&
Krause 2011; Gaffney et al. 2009). Another unnamed taxon is known from the Cenomanian of Madagascar (Lapparent de Broin \& Werner 1998; Lapparent de Broin 2000; Lapparent de Broin \& Guntupalli 2020). Many turtle taxa are incompletely preserved: some are known by their skull whereas other are so far exclusively documented by their shell (which is the case for the material described here). The result is the studies do not take into account (or only anecdotally) morphological data sets of capital importance (e.g. shell) making biased the attempts of phylogenetic reconstructions (Broin 1988 in Antunes \& Broin 1988; Lapparent de Broin \& Werner 1998; Gaffney et al. 2006) (see Lapparent de Broin \& Guntupalli 2020; Lapparent de Broin et al. 2020).

Until recently, the reported Pelomedusoides from Pakistan consisted of "Podocnemis" indica Lydekker, 1885 from the Paleocene of the Salt Range, Northern Pakistan, Eocene undetermined Pelomedusoides (Broin 1987; Smith et al. 2016), and early Miocene stereogenyine Podocnemididae (Wood 1970; Prasad 1974; Broin in Antunes \& Broin 1988; Gaffney et al. 2011; Pérez-García et al. 2017b; Ferreira et al. 2018). The former was initially reported as "Chelydidae" (corresponding to Podocnemididae), but it has been recently included into the Bothremydidae (Lapparent de Broin \& Guntupalli 2020). We show how Sindhochelys ragei n. gen., n. sp. cannot be attributed to this form although belonging to the same family. The discovery of two new bothremydid specimens in the Lower Paleocene Khadro Formation (Ranikot Group) of Sindh, Southern Pakistan, fills a gap in our knowledge about the evolution of the family in the Indian Subcontinent. The specimens are notably compared with the ornamented bothremydids including some Paleocene taxa such as Taphrophys sulcatus (Leidy, 1856) from the Cretaceous-Danian boundary of New Jersey (United States). New insights into the paleobiogeography of the family are provided.

\section{GEOLOGICAL AND STRATIGRAPHIC SETTING}

The term 'Ranikot Series' or 'infra-Nummulitic', first introduced by Blanford (1876), designates different lithological units sandwiched between the Upper Cretaceous Pab Sandstone and the early Eocene limestone and shales of the Laki Series ('Kirthar or Lower Nummulitic Group' of Blanford). Thus, the 'Ranikot' is classically considered as Paleocene in age, but the upper and lower boundaries of the Ranikot Group, as those of its three constituent subdivisions (in ascending order, Khadro, Bara, Lakhra Formations), remain poorly constrained chronostratigraphically. The main exposures of the Ranikot Group are in the North-South oriented anticlinal structures forming the Laki Range and extending between Thano Bula Khan in the South and Sehwan Sharif in the North (Fig. 1). In that area, Blanford $(1876,1879)$ distinguished in ascending order the Cardita beaumonti beds (= Glyptoactis (Baluchicardia) beaumonti (d'Archiac \& Haime, 1854)), clastics of the Lower Ranikot, and foraminiferal limestone and sandstone of the Upper Ranikot. The Cardita beaumonti beds is a lithological unit of variable thickness, characterized 
by a high concentration of the bivalve $G$. (B.) beaumonti, and these beds have been reported from various spots of eastern Neotethys (Douvillé 1928). Williams (1959) substituted the term Khadro Formation to the Cardita beaumonti beds of Blanford (1879) as the lowermost unit of the Ranikot Group and proposed a type section at Bara Nai (c. $20 \mathrm{~km}$ north from locality K18-12 that yielded the fossil described here), but the unit has not been properly defined, and the correlation has proven to be difficult laterally. In the Ranikot area, the Khadro Formation consists of olive, reddish to brown sandstone and shale resting unconformably on the Khaskheli altered basalts (Shah 2009; Agheem et al. 2011), the latter overlying the Campano-Maastrichtian Pab Formation.

Deposition of the Khadro Formation is interpreted to have occurred along the approximately North-South trending passive margin of eastern Neotethys, and the lithology and fossil content (Rage et al. 2014) suggest estuarine-coastal to inner shallow platform environments, which conforms to the known ecology of Bothremydidae.

Uplift and compression have been episodic since the Paleocene, but the main phase of compression, folding and uplift was during the Pliocene to the present (Schelling 1999).

The fossil specimens were collected on surface of a large platform of indurate sandstone (locality K18-12), which has also yielded the giant snake Gigantophis (Rage et al. 2014), crocodile remains, oysters, bivalves (?Crassatella sp.), and gastropods (Haustator sp.), suggesting a coastal depositional environment. The stratigraphic position of the locality K18-12 is indicated on the Waddi Sawri section (Fig. 1), which exposes the lower part of the Khadro Formation, including the Cardita beaumonti beds. The fossiliferous horizon is stratigraphically situated about 20 meters above the horizon of carbonaceous green sandstone showing the higher concentration of complete bivalves of $G$. (B.) beaumonti. The entire and measured Waddi Sawri section indicates that the thickness of the Khadro Formation does not exceed 80 meters in the Ranikot area. The complete carapace and plastron of turtle described here were recovered from the lower part of the Khadro Formation, just above the famous Cardita beaumonti beds (Blanford 1879). These beds lying near the base of the Khadro Formation indicate an early Paleocene (Danian) age (Cheema et al. 1977; Shah 2009). The Danian age of the Khadro Formation is supported by bivalves (Eames 1952) and foraminiferals (Nagappa 1959) assemblages. Thus, the bothremydid turtle described here is considered as early Danian in age.

\section{MATERIAL AND METHODS}

The shell and other fragments of turtles described here were collected during the 2012 field season from the same stratigraphic interval that yielded the giant snake Gigantophis (Rage et al. 2014). Because of its weight, the fossil shell was taken out from the sandstone in three blocks (Fig. 2) in order to make smaller plaster jackets to facilitate its long transportation to the field vehicle. The fossil shell was reassembled and meticulously prepared in Paris by Philippe Richir (CR2P), and Yohan Després (CR2P) made a resin jacket to facilitate its manipulation during detailed fossil study. In course of the preparation, many, marine and dwellers bivalves (Veneridae), have been found in the sandstone. They are articulated anatomical connection and probably still in live position (Fig. 2A1). This is consistent with the inferrent littoral ecology of bothremydids, most of the time. Taphonomically, the occurrence of venerids in life position inside the carapace indicates that the turtle was buried in low energy littoral environment. In the terminology, the plates overlapping the thoracic ribs are named costals and the scutes which cover them are named pleurals. The measurements are given in $\mathrm{cm}$ in Table 1 .

\section{ABBREVIATIONS \\ Institutions \\ AMNH American Museum of Natural History, New York; \\ BRGM Bureau de Recherches géologiques et minières; \\ CPAG Centre for Pure and Applied Geology, University of Sindh, Jamshoro, Pakistan; \\ DNPM Departamento Nacional da Produção Mineral, Rio de Janeiro; \\ ENSMP École nationale supérieure des Mines, Paris; \\ GSI Geological Survey of India, Kolkata; \\ MFL Main Fossiliferous Layer of the Hornerstown Forma- tion; \\ MHNM Musée d'Histoire naturelle, Marseille; \\ MNHN.F Muséum national d'Histoire naturelle, collection de Paléontologie, Paris; \\ MRAC Musée royal de l'Afrique centrale, Tervuren; \\ NJ New Jersey; \\ PU Princeton University.}

\section{SYSTEMATIC PALEONTOLOGY.}

Order TESTUDINES Linnaeus, 1758

Suborder PLEURODIRA Cope, 1864

Hyperfamily PELOMEDUSOIDES Cope, 1868

Superfamily PODOCNEMIDOIDEA Cope, 1868

Family BOTHREMYDIDAE BAUR, 1891

Genus Sindhochelys n. gen.

urn:Isid:zoobank.org:act:60DE5DBE-F7CE-4B17-9B04-971BDC06247F

TYPE SPECIES AND ONLY SPECIES OF THE GENUS. — Sindhochelys ragei $\mathrm{n}$. sp.

DiAGNOSIS. - Same as the type species of the genus.

ETYMOLOGY. - From Sindh, the province of discovery in Pakistan.

Sindhochelys ragei $\mathrm{n}$. gen., n. sp.

(Figs 2-9)

urn:Isid:zoobank.org:act:EC548A31-BD5A-478D-83D7-266EE85C9186

TYPE MATERIAL. - Holotype, a shell, CPAG-RANKT-V-3. The final repository of the fossil material reported here is the Centre for Pure and Applied Geology (CPAG), University of Sindh, Jamshoro, Pakistan. High-resolution casts are housed at the Muséum national d'Histoire naturelle, Paris. 

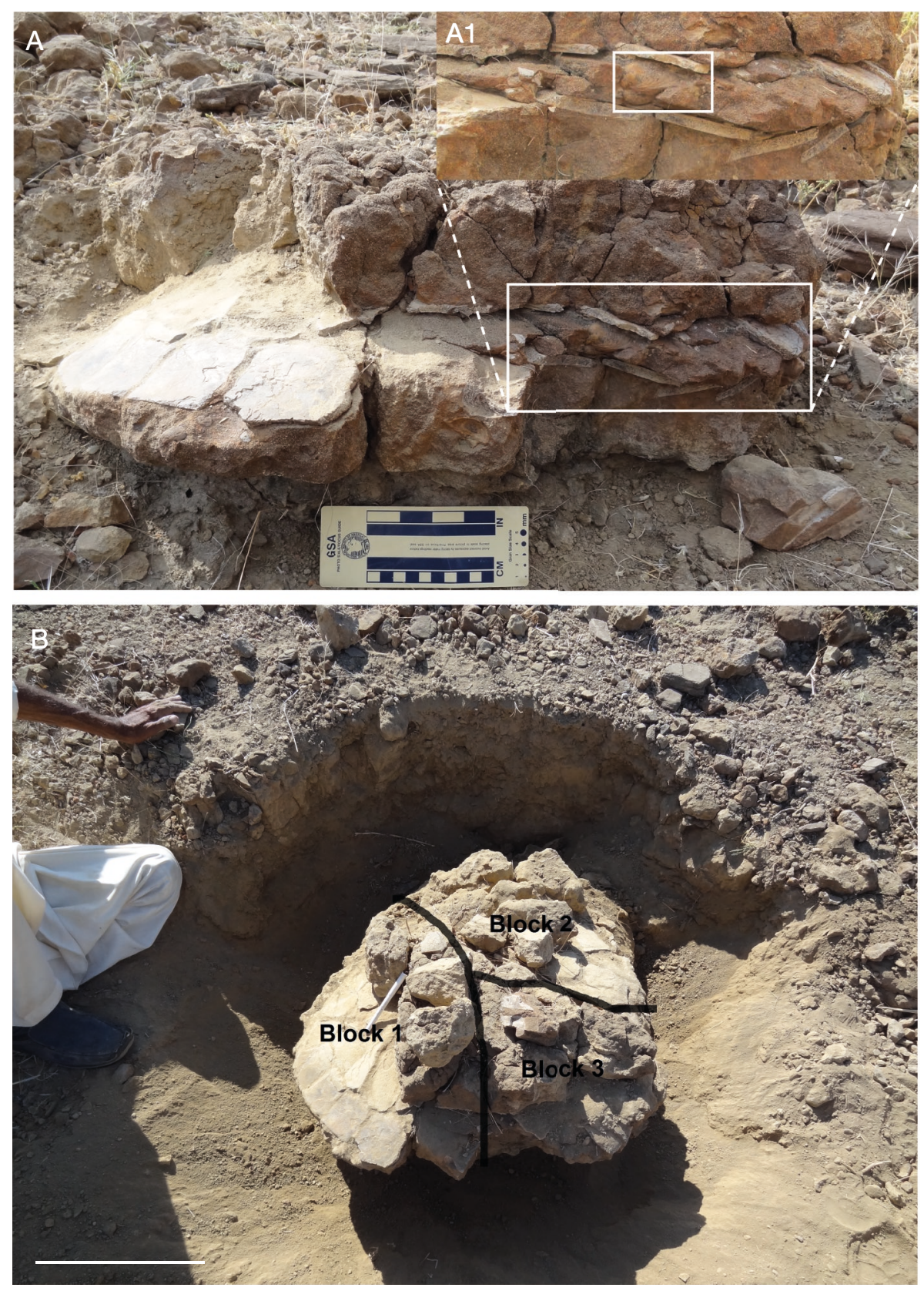

FIG. 2. - Turtle shell, CPAG-RANKT-V-3, holotype of Sindhochelys ragei n. gen., n. sp., in situ, during and after excavation at the locality K18-12: A, carapace in posterior view; A1, close-up of a lateral border showing the presence of a venerid bivalve in life position inside the carapace; B, carapace in dorsal view after excavation and split into three blocks. Scale bar: $30 \mathrm{~cm}$.

DiAgNOSIS. - For monotypic genus and species. A bothremydid turtle defined by the ornamentation of the shell consisting of raised well protruding polygons but, unlike other ornamented forms such as Taphrosphyini and Carteremys leithii, in having conjoined rather larger irregular polygons without a clear net of granulations, polygons clearly but irregularly protruding and either elongated or regularly polygonal, or open in dichotomic sulci at places. Sharing with Elochelys perfecta, Carteremys group, "Carteremys" pisdurensis, and Taphrosphyini the generalized plastral anterior lobe scute pattern of a long intergular, separating narrower and shorter gulars, and widely reaching the pectorals, intergular also separating the thus narrowed humerals; but: humero-intergularo-pectoral sulcus crossing the entoplastron at the $2^{\text {nd }}$ anterior third of its length, its humero-pectoral part posterior to the epi-hyoplastral suture in its median width, but close to it and laterally joining it, contrarily to E. perfecta where it is completely anterior to the suture, contrarily to "C." pisdurensis where it is medially anterior to the suture and lateroposteriorly inclined much posteriorly to the suture, and contrarily to Taphrosphyini and the Carteremys group where it does not cross the suture; intergularo-pectoral sulcus relatively transverse on the entoplastron, as in the Carteremys group, not being medially inclined in a marked V contrarily to E. perfecta, "C." pisdurensis and Taphrosphyini. Bothremydid carapace low with well-inclined bridges but different from other forms, being wider at the suture of peripherals 6-7; displaying a combination of other characters which are distributed in mosaic in the bothremydid groups such as: carapace anteriorly relatively elongated (with regard to primitive forms), at costals 1 , neural 1 and anterior peripherals, but moderately, and 


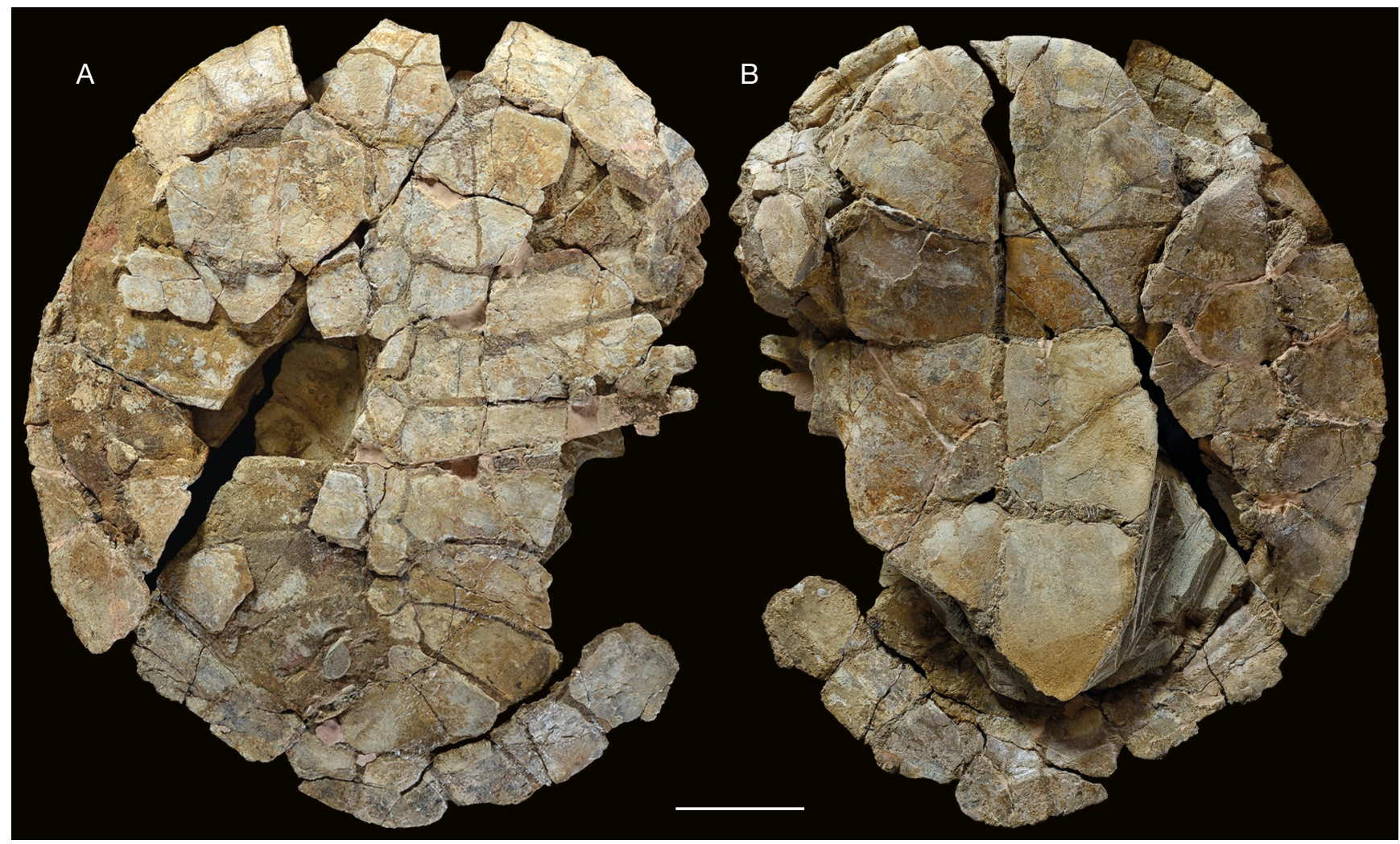

FIG. 3. - Sindhochelys ragei n. gen., n. sp., holotype CPAG-RANKT-V-3, from the Paleocene of Ranikot, locality K18-12, Southern Pakistan: A, B, shell photographs in dorsal (A) and ventral (B) views. Scale bar: $10 \mathrm{~cm}$.
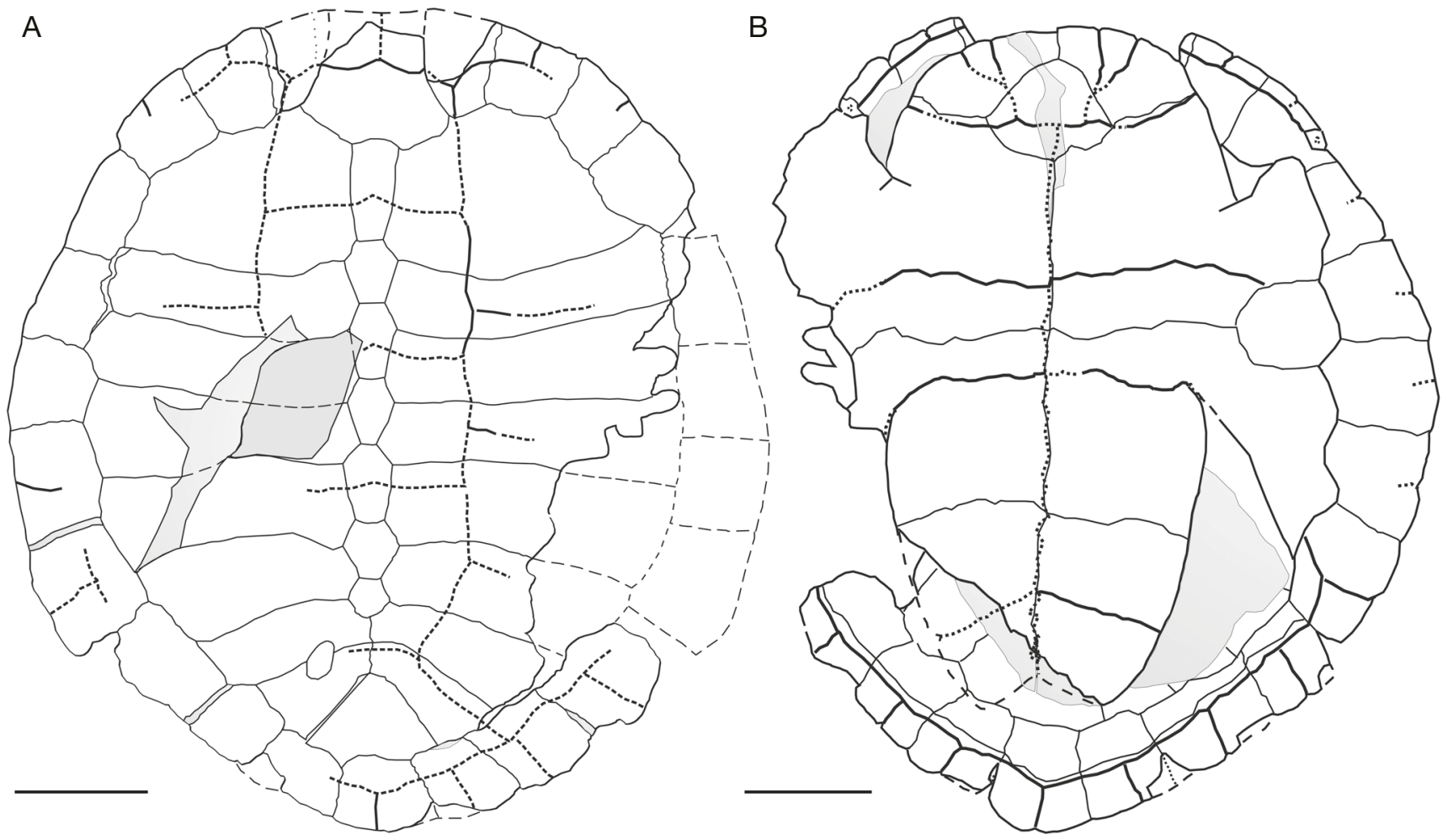

FIG. 4. - Sindhochelys ragei n. gen., n. sp., holotype CPAG-RANKT-V-3, from the Paleocene of Ranikot, locality K18-12, Southern Pakistan: A, B, shell drawings, in dorsal (A) and ventral (B) views. Scale bars: $10 \mathrm{~cm}$. 


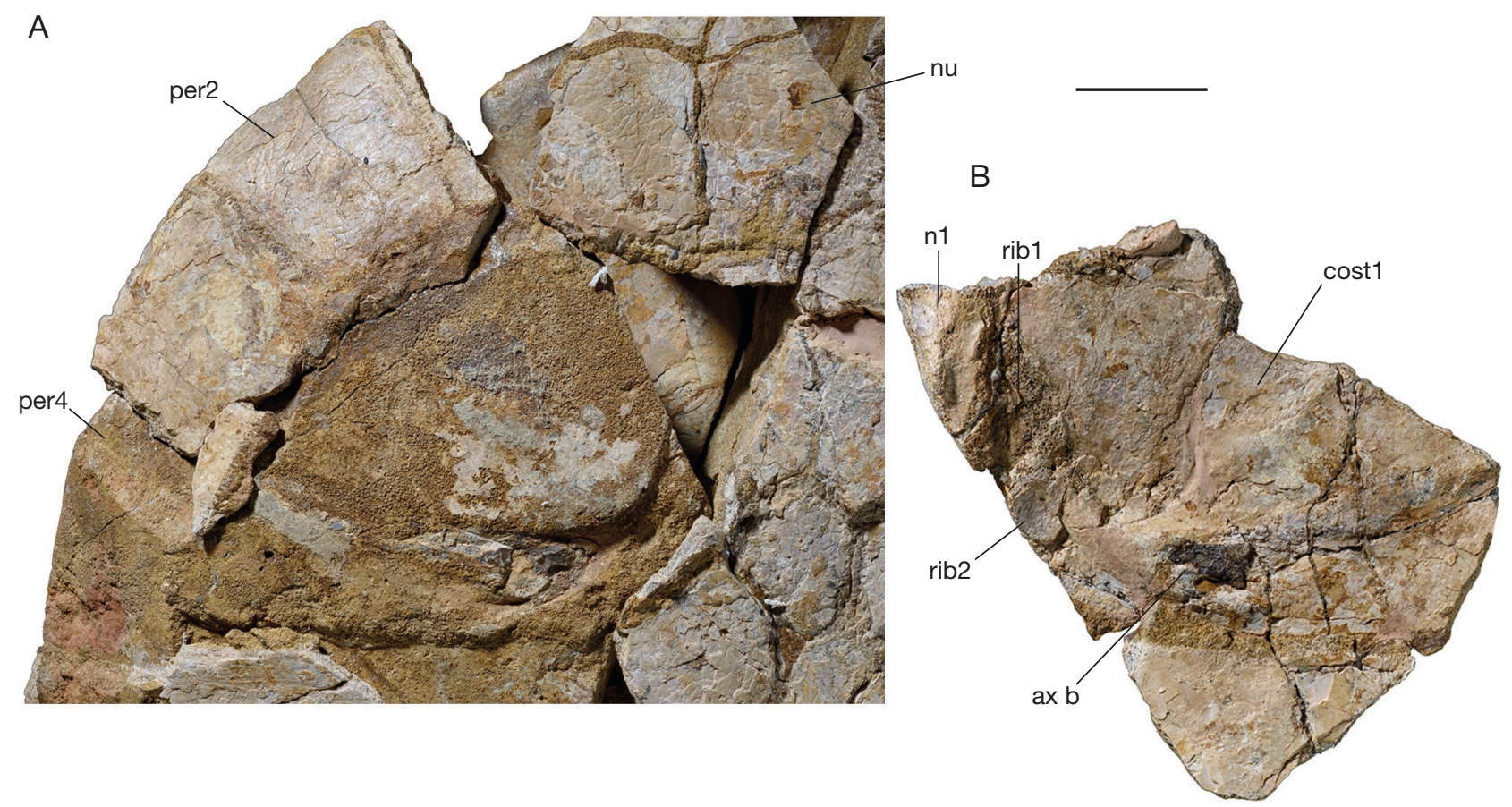

FIG. 5. - Sindhochelys ragei n. gen., n. sp., holotype CPAG-RANKT-V-3, from the Paleocene of Ranikot, locality K18-12, Southern Pakistan: A, anterolateral part of the carapace after removal of a part of the costal 1 with part of the neural I and the costal 2, to show the imprints of the thoracic ribs 1 and 2 , and axillary buttress, in dorsal view; B, same removed part in ventral view. Abbreviations: ax b, axillary buttress; cost 1, costal 1; n1, neural 1; nu, nuchal; per 2, peripheral 2; rib 1, rib 2, medial part of thoracic ribs 1 and 2 . Scale bar: $4 \mathrm{~cm}$.

with an anterior lateral convex contour and without medial nuchal projection; rounded marginal free border of the anterior peripherals; posterior contour slightly protruding towards pygal in a wide convex V; seven relatively narrow neurals; anterior and posterior (overall) plastral lobes not reaching the carapace borders in length; short trapezoid anterior lobe with lateral borders converging only a little towards the very gently convex transverse front, wider at base than the posterior lobe that is long; axillary buttresses laterally beginning at suture peripherals $3-4$, not particularly thinned, medially overlapping in a curve two thirds of the thoracic rib 2 and medially ending in a rounded extremity on the rib 2 and, contrarily to Taphrosphys sulcatus, rib 2 not close to the costals 1-2 suture towards the median part; rib 1 much anteriorly standing up close to the suture between costals 1 and 2; bridge (between axillary and inguinal notches bottom) longer than the anterior lobe and shorter than the posterior one, with upwards inclined lateral processes, massively shaped around the large (nearly as long as wide) mesoplastra and beside the wide bridge peripherals; posterior lobe with gently convex lateral borders little posteriorly converging. Long marginals 1 overlapping at least the anterior mid-length of the nuchal, and marginals 2 overlap laterally much shortening, in convex curve from peripherals 1 to peripherals 2, this short marginal overlap extending at least to the fourth peripherals (not preserved in situ on the specimen up to the peripherals 8 ), and with a short ventral marginal overlap; dorsally these short lateroanterior marginals correspond to long pleurals 1 , longer in relation to the following pleurals 2 to 4 ; vertebral 1 a little wider than the nuchal, $2^{\text {nd }}$ to $4^{\text {th }}$ as wide; possibly $4^{\text {th }}$ the longer; and $5^{\text {th }}$ the shorter, but posteriorly the wider. As in various other bothremydids, pectoroabdominal sulcus convex and slightly anterior to the mesoplastra, and curving towards them at its lateral extremity, and not posterior on the hyoplastron all along, contrarily to Taphrosphyini; femorals longer than pectorals, both long in relation to abdominals and anals.

Etymology. - From chelys, turtle in Latin. Species: in honor to our friend and colleague Jean-Claude Rage.
HORIZON AND TYPE LOCALITY. - Lower part of the Khadro Formation, Ranikot Group, early Paleocene (probably early Danian in age), type locality K18-12, in the proximity of Ranikot Fort, Jamshoro District, Sindh Province, Southern Pakistan (Fig. 1).

\section{DESCRIPTION (Figs 2-10) \\ Preservation}

The shell has been flattened during the fossilization, and the plastron is fractured at bridges and slightly pushed into the carapace. The carapace is therefore a little wider than when the individual was alive. A great part of the carapace was imbedded in a hard matrix, which could not be removed (Fig. 2), and a part of the plates were dislocated inside the whole assemblage. After the preparation, the elements of broken plates were not in contact, and they are preserved separately; some parts remained in the hard matrix. The photograph (Fig. 3) shows the preserved prepared part with plates in place or in imprints allowing a drawing of the full carapace and plastron (Fig. 4).

\section{Dimensions (Table 1)}

The shell is large (around $70 \mathrm{~cm}$ long) and the length/width ratio on (ca. 85 to $90 \%$ ) shows it was relatively high for the family, even taking into account the post-mortem flattening. The shell was clearly wider than in the more primitive Pelomedusoides and podocnemidoid forms of Brazil and Morocco. It is neither the smallest nor the largest known bothremydid fossil shell. The oldest and primitive Brazilian bothremydid Cearachelys has a shell length of $c .15 \mathrm{~cm}$ (Gaffney et al. 2006). Whereas some Maastrichtian shells from Niger have a length of 120 to $150 \mathrm{~cm}$ (Lapparent de Broin et al. 2020). Although much flattened post-mortem, the shell was however rather 


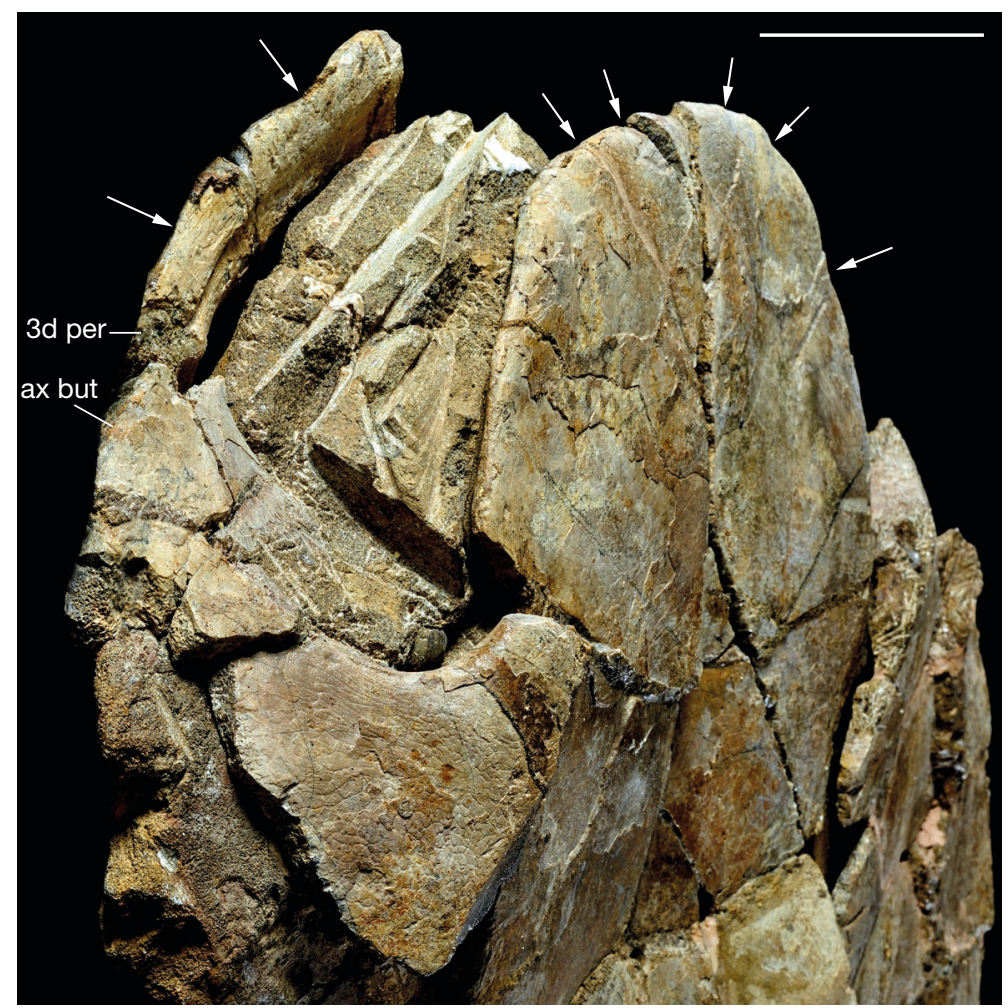

FIG. 6. - Sindhochelys ragei n. gen., n. sp., holotype CPAG-RANKT-V-3, from the Paleocene of Ranikot, locality K18-12, Southern Pakistan: left anterior part of the shell in oblique posterolateral view showing the delimitation of marginals 2 and 3 , and of plastral scutes by the indentation at the end of sulci border, and the ventral bulges of the scutes. Abbreviations: $\mathbf{a x ~ b}$, axillary buttress; $\mathbf{3 d}$ per, third peripheral. The arrows indicate ends of sulci at the border of the peripherals and anterior plastral lobe. Scale bar: $5 \mathrm{~cm}$.

low and gently rounded dorsally, without dorsal carina, and with well inclined bridges.

\section{Carapace (Figs 2-9)}

The maximum width is at the suture between the peripherals 6 and 7 (Figs 3A; 4A). There are no parallel lateral borders on a short length between the peripherals 4 to 8 , unlike most bothremydids: the contour widens from peripherals 2 to 6 and narrows from peripherals 6-7 contact up to the pygal. Anteriorly, the outline of the carapace is semicircular, being just straight at the nuchal area border (Fig. 4A). Posteriorly, the carapace reduces in width with a medial posterior protrusion, forming a wide $\mathrm{V}$. Thus, the carapace was not ovoid in shape, and its anterior part was not anteriorly longer and narrower, in relation to the less long posterior part. The anterior border of the nuchal 1 and most of the border of peripherals 1 is not preserved, but the contour may be reconstructed as transversally straight at the nuchal (Fig. 4A) and at medial part of peripherals 1 . Indeed, this part does not seem to have been much projected because of the very moderately inclined border of peripherals 2 and 3; this character differs from the condition seen in some taphrosphyine (sensu Lapparent de Broin \& Guntupalli 2020) bothremydids such as "Gafsachelys neurriregularis" Bergounioux, 1952 from the Ypresian of Gafsa (Tunisia) (Bergounioux 1956, pl. 10). Besides, the median carapace part has no parallel lateral borders, and the posterior part is not rounded as in some bothremydids such as Elochelys perfecta Nopcsa, 1931a (Nopcsa 1931b) from the Campanian of Fuveau-Valdonne (France). The anterior part of the shell is elongated in relation to the primitive condition seen in the oldest bothremydids such as Cearachelys (Gaffney et al. 2006). The maximal length of the costal 1 (at the suture of peripherals 2 and 3 ) is here as large as the length of the part including the costals 2, 3 and 4 at their mid width (measured following the surface curve). In agreement, the nuchal and peripherals 1 and 2 are also elongated. Although its anterior border is missing, it is clear the nuchal was elongated, but shorter than the costals 1 (Fig. 4A). The free border of peripherals 2 and 3 is not acute ; it is rounded as in some of the indetermined Bothremydidae from the Maastrichtian of Upparhatti (India) (Lapparent de Broin \& Guntupalli 2020: fig. 7); it is ventrally rounded with a short marginal scute overlap (Figs 3B; 6). The costal 1 is united by concave sutures: 1) anterolaterally to the posterolateral nuchal border and to peripherals 1 to 4 , and medially to the neural 1 ; 2 ) and by straight sutures to the anterolateral border of the neural 2 and with the costal 2 . The first peripheral is the narrowest of all the series, and it is overall narrow posteriorly, at its suture with the costal 1 . There are seven neurals. The neural 1 is narrow and elongated in agreement with the costal 1 . It is quadrangular, the longer of the series (in agreement with the costal 1 great length). Neurals 2 to 5 (hexagonal with short anterolateral sides) are narrow, and an individual variability in their shape and relative length is observed: 1) they have a narrow and nearly equidimensional contact between them but a narrower contact is situated between the neurals 4 and 5; and 2) they have a slightly different 
length, and a variable maximal width (at the junction of successive costals). Hexagonal neural 6 is shorter than neurals 2 to 5, and pentagonal neural 7 is even shorter, being the shortest in the series: both 6th and 7th have lateral sides which are as long anteriorly and posteriorly. The costals 7 partly posteriorly meet in the mid-line behind neural 7; the costals 8 are fully meeting medially. Costals 2 to 4 are approximately as long laterally as medially, costals 5 are laterally longer, and costals 6 to 8 are laterally longer and less wide (overall the $8^{\text {th }}$ ), accompanying the posterior carapace protrusion. The neurals 2 to 5 appear long because they are relatively narrow for their length, particularly the neurals 3 and 4, and evidently their length is in agreement with the costal length, i.e. they are not particularly long in the carapace. The suprapygal is pentagonal as usual in the family when the posterior costals 8 meet in the midline and the pygal is quadrangular, longer than wide in dorsal views (Figs 3A; 9C). In the dorsal views, the posteromedially pointed posterior border of the carapace appears shorter than the anterior one because the carapace is more inclined than the anterior border. On the left, part of the costal 6 and costals 7 and 8 are seen only by their impression: the transection of the iliac bone appears as an oval part in the matrix, between the $7^{\text {th }}$ and $8^{\text {th }}$ plates impression (Figs 3A; 9C), as usual below its suture with these plates.

It has been possible to separate a fragment with a good part of the neural 1, the left costal 1 and a triangular medial part of the costal 2, which allows to see its ventral aspect (Fig. 5B) and the corresponding impression of the carapace in dorsal view (Fig. 5A). The thoracic rib 2 is extended, below the costal 1 surface, medially from the interval between the neurals 1 and 2 towards laterally the peripheral 4; all along its course, it is rather close to the suture with the costal 2 but not very close, and not linked to it as in some forms. The thoracic rib 1 first extends (from laterally to medially) below the costal 1 along the medial third of the rib 2. Close to the medial border of the costal 1, rib 1 abruptly curves to extend anteromedially towars the level of the mid-length of the neural 1, where it sutured with the apophysis (not preserved) of the thoracic vertebra. The axillary buttress extends medially upon the thoracic rib 2 in a gentle curve, from the suture between the peripherals 3 and 4, and it covers the rib 2 on the two lateral thirds (Fig. 5A, B), making a rounded bulge ventrally (Fig. 5B). It medially ends in a rounded scar which is not dilated. In their median part, the axillary buttress and rib 2 are not as close to the suture between the costals 1 and 2 than in taphrosphyine specimens (Lapparent de Broin \& Werner 1998).

\section{Plastron (Figs 3B; 4B; 6; 7)}

It is nearly complete, missing most of the right xiphiplastron and the end of the left xiphiplastron, close to the anal notch, at the insertion of the ischion. The pelvis is concealed by the matrix and the shape of the pubis and ischiatic scars are unknown. However, in posterior view of the shell, the ischiatic contact with the xiphiplastron appears as making a transverse contact: there is no indication of the rounded scar of Taphrosphys sulcatus (Leidy, 1856) and other members of the taphrosphyine tribe (Gaffney 1975: fig. 11; Gaffney et al. 2006) (this tribe corresponding here to the Taphrosphys group of Broin in Antunes \& Broin 1988, i.e. Taphrosphyini sensu Lapparent de Broin \& Guntupalli 2020). The axillary notches are slightly deformed, better preserved on the right side. The bottom of the right inguinal notch is preserved, and the left one is partly cut by a crack; but its bottom position is indicated by the lateral end of the abdominofemoral sulcus on the hypoplastron, beside the crack, and conform to the right preserved side. The bridge length between the notches bottom was long, reaching approximately $36 \%$ of the full length of the plastron. The axillary buttress reaches the boundary between the peripherals 3 and 4 (Fig. 6), and the inguinal buttress reaches $2 / 3^{\text {rd }}$ of the peripheral 8 (Fig. $3 \mathrm{~B}$, left side).

The anterior lobe is wide so that it laterally covers rather well the axillary notches space, much occupying the anterior carapace opening in ventral view. It is trapezoidal with a wide transverse anterior border, barely convex, wide at its base and not reaching the anterior nuchal border. The epiplastral symphysis is short and the entoplastron is large in the anterior lobe. It is widely pyriform and its posterior extremity is posterior to the transverse line passing at the bottom of the axillary notches (Fig. 3B, right side). The bridge length between the axillary and inguinal notches is nearly as long as the posterior lobe. The bridge presents the great oblique surfaces of the lateral processes between the main plastral body and the corresponding ventral border of the wide peripherals. The large lateral mesoplastra are hexagonal, a little wider than long, their length representing about one third of the lateral bridge length. The posterior lobe is slightly less wide at its base than the anterior one. Its lateral borders, barely rounded just posterior to the inguinal notch bottom, are gently converging posteriorly towards the mid-line. The posterior lobe does not cover as much the inguinal notches space than in some other bothremydids, but more than in the primitive condition, in which lateral borders are straighter and more posteriorly converging (e.g., Francemys Pérez-García, 2019 [Pérez-García 2019a] and Cearachelys Gaffney, Campos de Almeida \& Hirayama, 2001 [Gaffney et al. 2001a]). It is likely that the anal notch was wide and short (doing a short and wide triangle).

The plastral plate length formula is: anterior lobe $<$ bridge $<$ posterior lobe length.

\section{Shell scutes}

An important part of the sulci is not preserved. Some are clearly visible, other are estimated (Fig. 4[dotted lines]). When not visible, their lateral extremity on the border of the element is positioned by the corresponding small incurved border of the plates, and by the sulcus continuation on the inferior face of the plates: this is seen by the border of marginals on the peripheral plates and by the border of plastral scutes on the epi-hyoplastra (Figs 3B; 4B; 6).

The carapace (Figs 3; 4) has long marginals 1 on the nuchal. These scutes are estimated as overlapping about the nuchal anterior mid-length (Fig. 4A). Dorsally, the sulci between the two marginals 1 and the vertebral 1 , corresponding to the posterior borders of the marginals 1 , are slightly concave. On the nuchal, the curve of the sulcus between the vertebral 1 , 
and marginal 1 and the sulcus between the marginal 2 and the vertebral 1 on the peripheral 1 helps identifying the possible position of the missing sulcus between the marginals 1 and 2: this was close to the nuchal-peripheral 1 suture (Fig. 4A[dotted line left side]). Each marginal 1 had to be a rectangular scute and barely wider than long. The marginal 2 was wide, long medially but laterally shorter, from the indicated right curve on the peripheral 1. It was followed by a short marginal 3. The following marginal sulci are mostly missing but from the 7 th marginal on the peripherals 6 and 7 , an overlap elongation is estimated, thanks to the preservation of parts of some sulci: as a whole, the marginal dorsal overlap seems to widen at the bridge and slightly narrow down after the bridge (from the peripherals 9 up to the pygal). This medioposterior marginal overlap is longer than that on the anterior peripherals. In conformity, ventrally, the marginals 8-9 sulcus, which is preserved on the left peripheral 8 , shows that the ventral marginal overlap is wide at this bridge $8^{\text {th }}$ peripheral, and then the ventral overlap is slightly reduced in length posteriorly. The anterior ventral carapace face indicates a short scute overlap and a rounded thick border (Figs 3B; 6). The ventral scuteskin boundary is marked: anteriorly to the bridge by a thin groove along a low bulge, and posteriorly to the bridge by a protruding rounded half-bulge. The vertebral 1 was wider than the nuchal (thanks to the preserved beginning of the sulcus on the right peripheral 1), the second (its right border being preserved) and third are estimated as equally wide or barely wider than the first, and the fourth seems to be posteriorly narrowed and in contact with the fifth vertebral on the costals 8 . If the vertebrals are correctly reconstituted, the longer vertebral is the $4^{\text {th }}$, as long as wide, while the $1^{\text {st }}$, the $2^{\text {nd }}$ and $3^{\text {rd }}$ are wider than long. By the preserved parts of sulci, the vertebrals 1 to 4 seem to be as wide all along, and they are not narrowed at their mutual contact, contrarily to the $4^{\text {th }}$ at its contact with the $5^{\text {th }}$. From the width of the posterior costals and their contact with the peripherals, it seems the vertebral 5 was posteriorly wider, on the peripheral 10, wider than the other vertebrals. Because of the shorter marginals 2 and 3 in Sindhochelys ragei n. gen., n. sp., the pleural scute 1 was the longest of the series and more than in many derived forms, those which also have an elongated anterior border.

The plastral scute sulci are mostly preserved (Figs 3B; 4B; 6). The anterior lobe scute pattern of $S$. ragei n. gen., n. sp. is estimated as a derived complex of scute arrangement. It is found in several taxa of several different podocnemidoid groups, but the details in the sulci outlines and scute proportions are different in each species, genus or group, and in particular in S. ragei n. gen., n. sp.: this derived "generalized anterior lobe scute pattern" is the intergular, which is wide and long, fully separates the short gulars and humerals, and widely reaches the pectorals. The particularities are here: 1) the position of the humeropectoral sulcus on the hyoplastron; 2) this close but posterior to the epi-hyoplastral suture; and 3) except reaching the lateral extremity of the suture on the left side. It is transversally positioned, following medially (intergular-pectoral sulcus part) to cross the entoplastron in the same direction, slightly posteriorly to the mid-length of

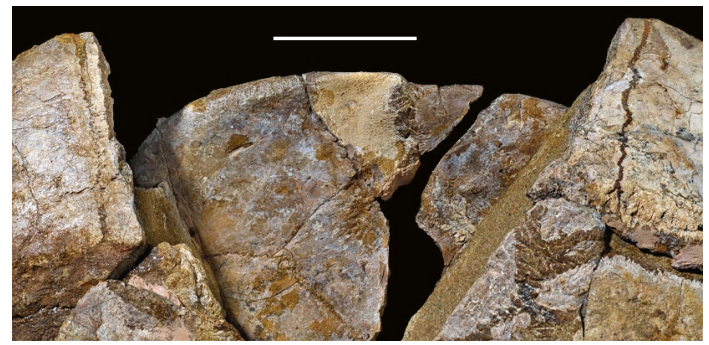

FIG. 7. - Sindhochelys ragei n. gen., n. sp., holotype CPAG-RANKT-V-3, from the Paleocene of Ranikot, locality K18-12, Southern Pakistan. Medioanterior part of the shell, the nuchal being removed, showing a part of the dorsal face of the anterior lobe with the sulci limiting the overlapping scales. Scale bar: $5 \mathrm{~cm}$.

the plate; its direction is transverse as a whole and it is not incurved in a V medially on the entoplastron, contrarily to some Taphrosphyini including Taphrosphys sulcatus (in Hay, 1908), the Carteremys group and "Carteremys" pisdurensis Jain, 1977 (in Jain 1986) (Lapparent de Broin \& Guntupalli 2020), and Elochelys (see Nopcsa 1931b; Gaffney et al. 2006); it is not laterally posteriorly directed towards the hyoplastral border contrarily to "Carteremys" pisdurensis in Jain (1986). Sindhochelys ragei $\mathrm{n}$. gen., n. sp. characteristic gular-intergular pattern is: 1) the intergular is notably large; its precise borders are not well visible but its posterior width is estimated at its medial spring from the pectorals on the anterior two/thirds of the entoplastron; it is wider than each gular; it appears as wide all along the entoplastron, with possible parallel or nearly parallel lateral borders, but it becomes slightly wider between each gular on the epiplastra; and 2) each gular is shorter, and nearly reaches or not (at least on left side) the epientoplastral suture. The border extremities of the scutes is visible. This is seen (Figs 3; 6) at the incurved end of the intergular, gulars and humerals with their rounded border and by their ventral surface, which is slightly, individually, ventrally protruding (Fig. 6). The short plastral anterior scute overlap is visible on the dorsal face of the anterior lobe (Fig. 7). The posterior scute sulci are mostly visible. They are completed by symmetry on the Figure $4 \mathrm{~B}$. The pectoroabdominal sulcus is a little convex, positioned just anterior to the mesoplastra and reaching it, as seen on the left side. The abdominofemoral sulcus is also convex and its lateral left end indicates the bottom of the inguinal notch. The femoroanal sulcus is positioned on the xiphiplastron nearly parallel to the hypo-xiphiplastral suture, and it seems to be at mid distance from this suture and from the possible xiphiplastral extremity, if not slightly closer to the suture than to the anal notch.

The plastral scute length-formula is (medially except mediolaterally for humerals): femorals $>$ pectorals $>$ anals $>$ abdominals $=$ intergular $>$ humerals $>$ gulars.

\section{Shell ornamentation (Figs 8; 9)}

The whole shell surface is relatively damaged. As the turtle is very large, the general view does not show the surface details, so that we enlarged several small decorated parts representing the variability (Figs 8 ; 9AD). The shell was decorated by a net of meeting sulci delimiting irregular polygons, variable 
in shape and proportions according to the position on the plates but relatively large on the whole, and protruded, i.e. much raised on the surface of the carapace and in relation to the sulci between the polygons. They are often damaged, their external surface being eroded, so that the complete depth of their protrusion (above the general surface) is not everywhere preserved (Fig. 8B, D). Some of the figures show imprints of the external surface in the matrix (Figs 8A; 9D). The polygons are either as wide as long or longer than wide. There are also places of short dichotomic sulci which are not united in polygons, and represent a usual basic decoration in aquatic turtles, but the elements have here a relatively marked length. In the right hyoplastron (Fig. 8C), there are short sulci, not united in a net, which follow the lines of the growing radiation of the pectoral scute (from the radiation center, situated towards the axillary buttress) (Fig. 3B). On the whole, on the external surfaces, the raised polygons are not regular and well delimited, and not as much protruding as in Taphrosphys sulcatus (Leidy, 1856), the type species of the genus (Fig. 9E-G). However, the less eroded part of the inner border of the peripherals 2 and 3 show smaller and well-delimited polygons 1 (Fig. 9B), and there are also such polygons on the suprapygal (Fig. 9C), which are rather more similar to those of T. sulcatus. But they do not constitute an as well constituted net of granulations protruding on the whole shell surface.

\section{COMPARISONS}

General comparisons of the carapace of Sindhochelys ragei n. gen., n. sp. with Bothremydidae

The carapace of Sindhochelys ragei n. gen., n. sp. differs from that of other bothremydids in a combination of unique features: 1) it has no parallel lateral borders in its middle part; 2) it is rounded as in various other bothremydids but differently by the position of its largest width at peripherals 6-7 sutures and not posteriorly; 3 ) together with an anterior rounded border anterior to this line; border that was straight just at nuchal border and probably the medial part of the peripheral 1 , but not making a medially protruding carapace at nuchal area; and 4) and together with the slightly pointed in $\mathrm{V}$ posterior border. All that makes the carapace neither rectangular nor ovoid. It is distinct from the more rectangular to ovoid shape with long parallel median lateral borders of various other bothremydid forms.

However, some features of $S$. ragei n. gen., n. sp. are distributed in mosaic in various bothremydid species. The shape of the carapace of $S$. ragei n. gen., n. sp. shows similarities with the rounded shell of the holotype of the bothremydine Chedighaii barberi (Schmidt, 1940) (Gaffney \& Zangerl 1968) from the late Cretaceous (Campanian) of Arkansas (United States); in this form, the lateral profile shows a moderate height and much oblique bridges (Schmidt 1940: figs 3 and 4) as, for example, in Francemys (from Gadoufaoua) and Eusarkia rotundiformis Bergounioux, 1952 - "Gafsachelys" group (a Tunisian Ypresian taphrosphyine); such relatively high inclined bridges were probably present in $S$. ragei n. gen., n. sp. because of the wide bridge processes and the large width of the shell, making it it rather low (Fig. 2); but its inclination angle also exists in other wide bothremydids shells. The bothremydine species $C h$. barberi is also figured under the name Podocnemis alabamae Zangerl, 1948 (Zangerl 1948: fig. 4.1) (Campanian) (a junior synonym, see Gaffney et al. 2006), by a specimen which differs in a slight intraspecific variability in width, usual in turtles: some individuals are slightly wider than others, thus appearing shorter, which is an intraspecific difference known as sexual dimorphism in living forms. Both $C h$. barberi specimens are large individuals (maximal lengths between 58.2 and $65 \mathrm{~cm}$ ). But in this species, the widest margin is at the peripheral 7 (posterior to the suture 6-7) and the anterior peripherals and nuchal are less elongated and wide. Beside this difference, S. ragei n. gen., n. sp. differs in the less medially inclined borders of peripherals 2 and 3, an anterolaterally wider costal 1 and a longer costal $1+$ neural $1+$ nuchal part; probably it differs also in the absence of a nuchal notch, on a nuchal that is narrower for its length and anteriorly relatively wider in $S$. ragei n. gen., n. sp. Sindhochelys ragei n. gen., n. sp. has lateral borders of plastral lobes less oblique; the anterior lobe is relatively slightly shorter and anteriorly wider, being more trapezoidal with lateral borders less converging anteriorly, and the posterior lobe is less wide: all that is seen when the carapaces are adjusted in width and length and superposed. The shell of $C h$. barberi (from these two specimens) is more similar to that of another bothremydine, Rosasia soutoi Carrington Da Costa, 1940, from the late Cretaceous (Campanian) of Portugal (Antunes \& Broin 1988), sharing a shorter carapace anterior part than in $S$. ragei n. gen., n. sp., and an anterior border with a notched and anteriorly narrower nuchal; the carapace of $R$. soutoi is more regularly rounded than in $C h$. barberi, with a short median length of parallel lateral borders.

By its large size and Paleocene age, the carapace of Sindhochelys ragei $\mathrm{n}$. gen., n. sp. can be compared with the large carapace of Puentemys mushaisaensis Cadena, Ksepka, Jaramillo \& Bloch, 2012, from the Paleocene Cerrejón Formation (Colombia) (maximal carapace length: $118 \mathrm{~cm}$ ). But the latter has differently inclined borders of peripherals 2 and 3 , because of an overall medially elongated and protruding nuchal part, giving a more elongate and more oval anterior carapace. This shape differs from what is observed in $R$. souto $i$ and $C h$. barberi (Bothremydini) and $S$. ragei n. gen., n. sp., as well as from that of Foxemydina Gaffney et al. 2006; this is a late Cretaceous European infratribe in which Puentemys has been included by Cadena et al. (2012). Rosasia soutoi and $P$. mushaisaensis have 7 neurals as in $S$. ragei n. gen., n. sp.. But in $P$. mushaisaensis, these neurals are much wider, as such is also the vertebral 1 anteriorly, which reaches the peripherals 2 . Besides, the plastral lobes of $P$. mushaisaensis are particularly distinctive. Its anterior lobe is relatively longer and anteriorly narrower (in agreement with the dorsal carapace border), whereas the posterior lobe is wider and much more rounded, filling the opening space of the posterior carapace including the inguinal notches.

The bothremydines $R$. soutoi, Ch. barberi and P. mushaisaensis surely do not belong to the group of Sindhochelys because, 

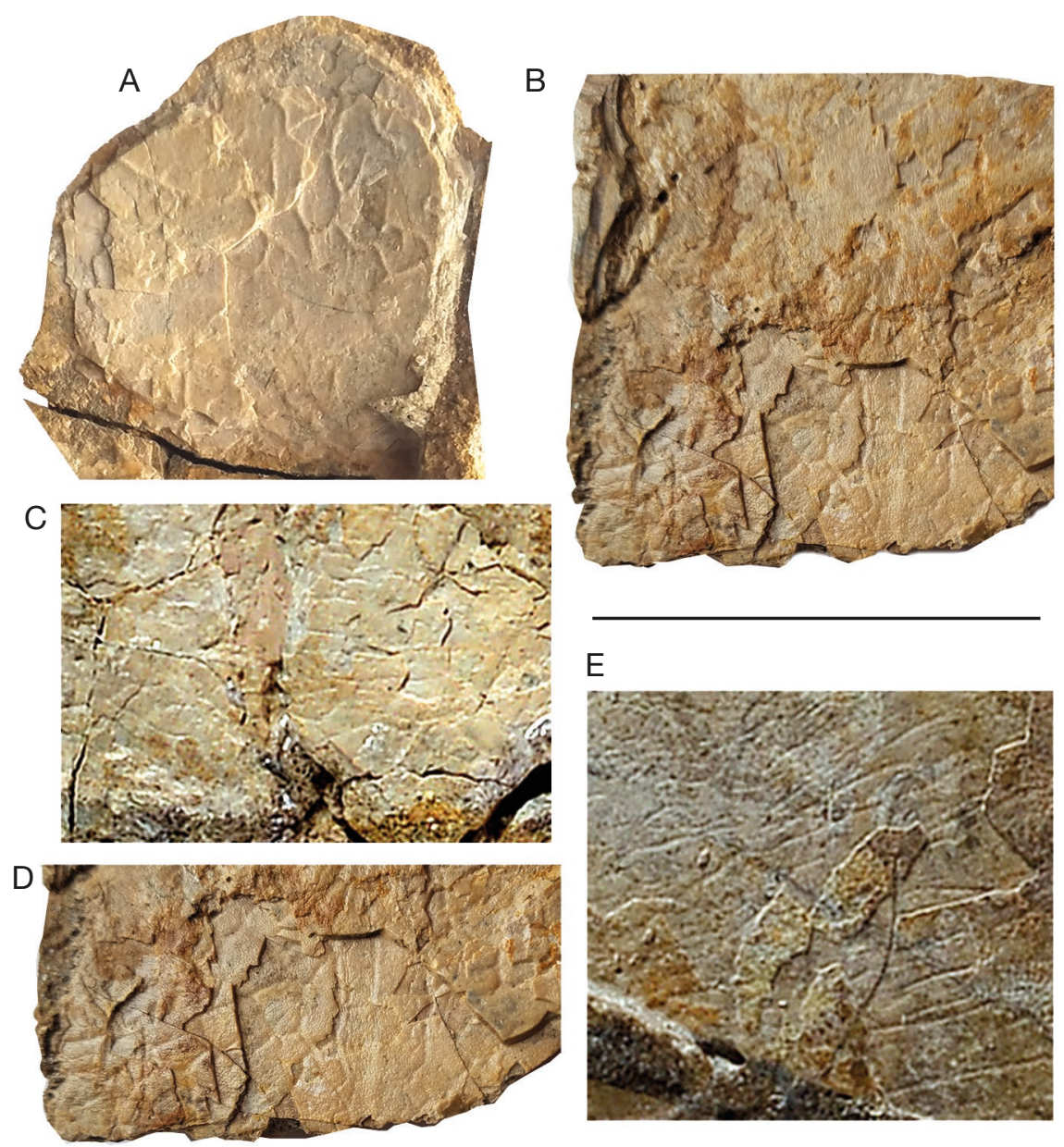

FIG. 8. - Sindhochelys ragei n. gen., n. sp., holotype CPAG-RANKT-V-3, from the Paleocene of Ranikot, locality K18-12, Southern Pakistan. A-D, decoration in various parts of the shell: $\mathbf{A}$, isolated piece with the imprint of the mesoplastral external surface; $\mathbf{B}$, marginal part of peripheral 10, dorsal view; C, left costal 1 part, posterior border at mid-width, dorsal view; D, a costal lateral border, in dorsal view; E, right hyoplastral part, ventral view. Scale bar: $5 \mathrm{~cm}$.

beside their own derived particularities, they differ from $S$. ragei $\mathrm{n}$. gen., n. sp. in primitive features, which are also present in many other bothremydids (features which are derived in $S$. ragei n. gen., n. sp.): 1) the primitive plastral anterior scute pattern with an intergular separating the smaller gulars, longer than them but not reaching the pectorals, so that the humerals meet medially; 2) the absence of any well marked polygonal ornamentation. Chedighaii barberi ornamentation is described thus (Gaffney et al. 2006): "Shell surface texture is the "pelomedusoid" pattern (Broin, 1977)" (p. 551) "consisting of fine forking and irregular vascular grooves" (p. 548), i.e. the basic decoration seen in aquatic forms. Rosasia soutoi also presents a basic decoration (Carrington da Costa 1940: fig. 2). In P. mushaisaensis: "The carapace is smooth, lacking decoration on the surface in the holotype and all referred specimens" (Cadena et al. 2012: 691). All the other species presenting together the basic decoration (more or less marked) - or lacking any description and figure of the decoration - and a primitive plastral scute pattern, have a more different contour of carapace and plastron, even if many other details may be similar and distributed in mosaic in others, such as the elongation degree of the anterior cara- pace border, for example. Some specimens of a species have a more marked decoration than others, such as the specimen from the Cenomanian of Portugal attributed to Algorachelus peregrinus Pérez-García, 2016 by Pérez-García et al. (2017a): such a decoration is not visible in the figured type series specimens of $A$. peregrinus Pérez-García, 2016 from Spain (Pérez-García 2018a). Elochelys perfecta Nopcsa, 1931 (France) (two known specimens) has also, similarly to this Portuguese Algorachelys specimen, a more marked basic decoration of mostly elongated polygons, which are not raised in relation to $S$. ragei n. gen., n. sp. The nuchal of an undetermined Pelomedusoides from the Eocene of the Gujarat Province (India) (Smith et al. 2016) presents such a well-marked basic decoration of not raised small polygons. However, unlike in Algorachelus, Chedighaii, Rosasia and Puentemys, E. perfecta shares with Sindhochelys the derived "generalized plastral scute pattern", defined by an elongated intergular, fully separating the humerals up to the pectorals. However, within this frame, E. perfecta differs from $S$. ragei n. gen., n. sp. in the anterior position of the humero-pectoral sulcus. In $E$. perfecta, it is anterior to the epihyoplastral suture and, medially the intergular is $\mathrm{V}$ shaped on the entoplastron, with the $\mathrm{V}$ 
point posterior to the epihyoplastral suture level: that makes a clearly distinct contour and proportion of the intergular in both species. Besides a moderate decoration and the different intergular shape, the shell shape of E. perfecta differs from that of $S$. ragei n. gen., n. sp. in a suite of features such as the anteriorly and posteriorly more rounded carapace, with parallel lateral borders on a small median length and with an anterior rounded protrusion, and a different plastron by the more rounded anterior plastral lobe, and the wider and more rounded posterior lobe.

Particular comparisons of Sindhochelys ragei $n$. gen., n. sp. with some Indian Bothremydidae

Alone in India, two Indian bothremydid species share one or two of the most important general derived features of $S$. ragei n. gen., n. sp.: the generalized anterior lobe scute pattern as in E. perfecta (in the above compared forms) and the protruding polygonal ornamentation (unlike the above compared forms).

1) Carteremys leithii (Carter, 1852), sharing both features with Sindhochelys ragei n. gen., n. sp. C. leithii from the Upper Cretaceous (Maastrichtian) intertrappean- beds of the Worli Hills (Mumbai, India) has been revised and figured by a specimen (GSI coll. no. 20337) in Williams (1953: pl. 3). This has been designed as neotype in Lapparent de Broin \& Guntupalli (2020). Williams's photograph is not fully informative but the decoration is visible on the figure and described by Williams (1953: 6) as follows: "the characteristic sculpture of the surface (mentioned by Carter), which, while somewhat like that of some chelyid, also resembles that of, for example, the American pelomedusine genus Taphrosphys". This sculpture particularly appears on his figure, on the left costal 1 , as made of small polygons that are well protruded and regularly elongated: the polygons are more regular and smaller than in $S$. ragei n. gen., n. sp. They appear as more similar in outline to those of Elochelys perfecta but differ in the well-marked protrusion. The plastron of $C$. leithii is known by an incomplete drawing of Carter (1852), missing the sutures of the anterior lobe plates. The anterior plastral scute pattern has similarities with that of $S$. ragei n. gen., n. sp. This is particularly visible in the long intergular separating the humerals and reaching the pectorals. However, the intergular contact with the pectorals is just marked by a point in the drawing. This short punctiform contact is rather unusual; it is known to occur as a variable feature in some specimens of the podocnemidid Neochelys arenarum Broin, 1977, beside a wider contact in other specimens. However, other specimens of the Carteremys group from India complete the shape variability for the species group, with the intergular having a wider contact with the pectorals (Lapparent de Broin et al. 2009; Lapparent de Broin \& Guntupalli 2020). The shape of the carapace of C. leithii (as revised by Williams 1953) is very distinctive from that of $S$. ragei n. gen., n. sp. and E. perfecta: it is anteriorly narrower, with a different proportion of enlarged peripheral part and nuchal, and with the widest carapace part at the $7^{\mathrm{th}}=8^{\text {th }}$ suture, which is posterior to the peripherals $6-7$ contact of $S$. ragei n. gen., n. sp.

and 2) "Carteremys" pisdurensis Jain, 1977, sharing the generalized scute pattern with Sindhochelys ragei n. gen., n. sp. "C." pisdurensis from the Upper Cretaceous (Maastrichtian) Lameta Formation (infratrappean beds) of (India) also has a similarly generalized scute pattern on a drawing of Jain (1986: fig. 3, for "Shweboemys" pisdurensis). But the humero-pectoral sulcus is just anterior to the epihyoplastral suture level, medially on the entoplastron, and it becomes posterior and oblique towards the external hyoplastral border, while the intergular shape is posteriorly wide in a $\mathrm{V}$ on the entoplastron: the drawing of the sulci is not visible on the photographs, and the drawing of the carapace is problematic on the nuchal part (the form needs to be reexamined to rename the genus, see Lapparent de Broin \& Guntupalli 2020). Contrarily to Sindhochelys ragei n. gen., n. sp., the shell is not decorated and the shape of the carapace is clearly not similar: on the photographs, the carapace is quadrangular and not oval, medially widened toward the midline, contrary to Jain's drawing.

Particular comparisons of Sindhochelys ragei $n$. gen., n. sp. with Taphrosphyini

The members of the tribe Taphrosphyini Gaffney, Tong \& Meylan, 2006, emend. Lapparent de Broin \& Guntupalli (2020) present the two characters shared by the Carteremys group beside differences which characterize the Taphrosphyini tribe. In this work, this tribe is restricted to the Taphrosphys group of Broin (1988) in Antunes \& Broin (1988), contrarily to Gaffney et al. (2006) and Pérez-García (2019b). All the species included by Gaffney et al. (2006) in their "taphrosphyine" tribe which have no Taphrosphys decoration, carapace shape other than that of Taphrosphys, and presenting other different characteristics of skull, are united in the tribe "Nigeremydini Gaffney et al., 2006" new rank in Lapparent de Broin \& Guntupalli (2020) (i.e. basically the Nigeremys group of Broin in Antunes \& Broin [1988]) (Lapparent de Broin et al. 2020). Besides their different anatomy, by their stratigraphical first appearance as soon as late Cretaceous and wide geographical diversification, the Taphrosphyini of Gaffney et al. 2006 (emended) cannot be the sister group of the Azabbaremys-Acleistochelys clade of Gaffney et al. 2006 (Gaffney et al. 2001c, 2006, 2007), a Malian Paleocene clade which is the youngest element of Nigeremydini. This tribe is a group of large turtles living in the Maastrichtian-Paleocene Trans-Saharan seaway, extending to Neotethys as a gulf or a full passage (according to the age) in the African craton (Halstead 1979; Walker 1979; Lapparent de Broin \& Werner 1998; Lapparent de Broin 2000; Lapparent de Broin \& Guntupalli 2020; Lapparent de Broin et al. 2020). Thus, newly understood and emended, Taphrosphyini tribe is represented by the type species Taphrosphys sulcatus (Leidy, 1856) from the early Paleocene (Danian) of New Jersey, although the tribe is already widely diversified at Maastrichtian times (Africa, Syria, France). It is defined by shell features such as: 1) the autapomorphic long pubic scar and small rounded 


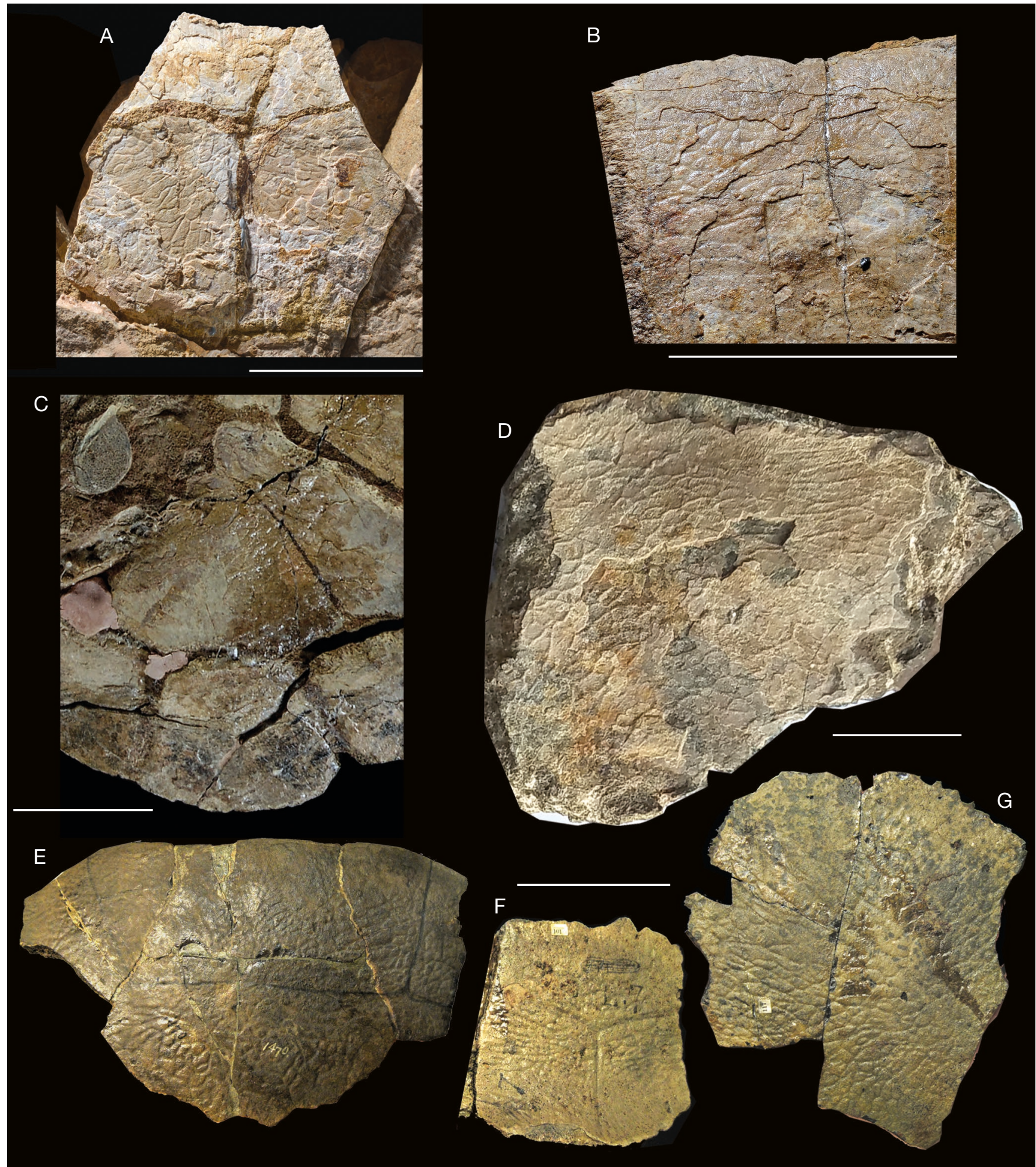

FIG. 9. - Comparison of the decoration of Sindhochelys ragei n. gen., n. sp. from the Paleocene of Ranikot, locality K18-12, Southern Pakistan, and Taphrosphys sulcatus (Leidy, 1856) from the early Paleocene of New Jersey (United States): A-D, Sindhochelys ragei n. gen., n. sp., holotype CPAG-RANKT-V-3: A, nuchal part; B, left peripherals 2, dorsal face with smaller polygons than in other parts; C, suprapygal-pygal part, dorsal views; D, imprint of an isolated plate, ventral view; E-G, Taphrosphys sulcatus: E, AMNH 1470, "Barnsboro, N.J." (Cope collections), nuchal border of three plates, dorsal view; F, G, AMNH 2522, "Tinton Falls, N.J.», syntype: F, peripheral 6 (medial plate of three in Leidy (1856: pl. 19, fig.4), and in Gaffney et al. (2006: fig. 20), dorsal view; G, xiphiplastron, ventral view. Scale bars: A-C, E-G, $5 \mathrm{~cm}$; D, $2 \mathrm{~cm}$.

or triangular spot of the ischiatic scar (which is situated at the border of the anal notch of the xiphiplastron) (Gaffney 1975: fig. 11; Hay 1908: fig. 118; Pérez-García et al. 2018); and 2) to which is obligatorily added the regular decoration of protruding small polygons (Fig. 9E-G) and the generalized scute pattern of the anterior lobe. 
Taphrosphys sulcatus (Leidy, 1856) representative of the Taphrosphyini tribe

Thus, all the referred specimens to Taphrosphys have the generalized anterior lobe scute pattern (above defined), like that of Sindhochelys ragei n. gen., n. sp. The syntype of T. sulcatus, AMNH 2522 (under the name of Platemys sulcatus Leidy, 1856) is of unknown locality and horizon ("Tinton Falls, N. J." in Leidy 1865: 109), without any further information except that it belongs to the Hornestown Formation, which was first attributed by Gaffney (1975) to the late Cretaceous. The syntype consists of a fragment of $5^{\text {th }}, 6^{\text {th }}$, and $7^{\text {th }}$ left peripherals (Leidy 1865: pl. 19, fig. 4, a drawing reproduced in Gaffney et al. [2006], fig. 20, reproduced in part in Fig. 9F) and a left xiphiplastron (Fig. 9G). Gaffney et al. (2006) noticed that if only the peripherals were figured by Leidy, it is the xiphiplastron that has the diagnostic features of the genus and it may become the lectotype. Moreover, the fossil MFL area of the Hornerstown Formation that yielded all the T. sulcatus specimens is now considered as basal Danian (Gaffney et al. 2006), as is $S$. ragei n. gen., n. sp. No more photographs of the shell were given except one photograph of a dorsal incomplete shell (specimen PU 18707, from Sewell [N. J.] in Gaffney [1975: fig. 5]) with a reconstructed contour; the polygonal ornamentation, similar to that of the Fig. $9 \mathrm{E}-\mathrm{G}$, is barely visible, as well as on Gaffney's figure 5 as on the field photograph of the dislocated specimen PU 18707 in situ. For the reconstruction of the carapace shape of T. sulcatus, beside that of PU 18707 (Gaffney 1975), we consider the figures of Hay (1908) from various incomplete New Jersey specimens, which were attributed to various species including the species T. leslianus Cope, 1870, T. (Prochonias) longinuchus (Cope, 1870) and T. molops Cope (1870) (all species synonymized with sulcatus in Gaffney [1975]). Among others, Gaffney et al. (2006) mentioned the specimen AMNH 1470, from Barnesboro (N. J.), which notably includes the anterior carapace part, described as T. molops by Hay (1908: 119) and figured here (Fig. 9E). As the syntype, it shows the specific ornamentation, and besides, a contour of the anterior margin of the shell that conforms that of the other preserved specimens, as figured in Hay (1908) and preserved in the AMNH fragments.

\section{Comparison of the ornamentation of Sindhochelys ragei} n. gen., n. sp. with Taphrosphyini

The comparison of the nuchal ornamentation of T. sulcatus with that of Sindhochelys ragei n. gen., n. sp. shows a rounded granulation of smaller and more regular polygons (Fig. 9E-G compared with Fig. 9A-D and Fig. 8). Open dichotomic sulci of $S$. ragei n. gen., n. sp. carapace parts (Fig. 8C, E) are not known in the T. sulcatus assemblage of photographed specimens. Various elements of carapace and plastron of other Taphrosphyini present a decoration similar to that of T. sulcatus and are known by photographs, such as T. congolensis Wood, 1975 from the Paleocene of Angola (Wood 1975; Pérez-García et al. 2018) (our observation at MRAC). Other taphrosphyine forms may also include raised polygons and dichotomic sulci at some places, such as Eotaphrosphys ambiguus (Gaudry, 1890) from the Maastrichtian of Mont-Aimé (France)
(MNHN.F.MTA1) (Broin 1977; Montenat \& Merle 2018: fig. 164B1, D1; Pérez-García 2018b), which displays some similarities with those of S. ragei n. gen., n. sp. (Figs 3A; 8; 9A-D). Well raised irregular and regular polygons are present in another taphrosphyine, the Eusarkia-"Gafsachelys" group of the Ypresian of Gafsa (Tunisia) (Bergounioux 1952, 1956). There also, on the whole a more evident net is always present. The polygons radially diverge from a scute center, to become elongated on the borders, as in S. ragei n. gen., n. sp., T. sulcatus elements (Fig. 9E-G) and Eotaphrosphys ambiguus for example. This radiation is visible in $S$. ragei n. gen., n. sp. on the nuchal and suprapygal (Fig. 9C), but the polygons differ in size and shape. This Tunisian group is an assemblage of undefined number of "species" (see a discussion in Moody (1972), Broin (1977), Gaffney et al. (2006)). It was established on several individuals where the decoration has its variabilities, beside the variable medial union of the costals over the neurals but with the constant medioanteriorly protrusion of the ovoid carapace, the longest known protrusion in the tribe. The group includes Eusarkia rotundiformis Bergounioux, 1952 (Bergounioux 1952: pl. 1-2) (holotype MNHN.F. coll.) mostly smoothened surface by erosion and lacking the anterior border, Gafsachelys neurriregularis Bergounioux, 1952 (pls 3-4) and Bergounioux 1956 (pls 10[2], 11, 12 and 13), G. moularensis Bergounioux, 1956 (Bergounioux 1956: pl. 10[1]), and Euclastochelys interrupta Bergounioux, 1956 (Bergounioux 1956: pls 14, 15), all variably preserved. The part of shell named Gafsachelys phosphatica Bergounioux, 1952 (ENSMP, MNHN.F deposit) is a nomen dubium. It cannot be the type specimen of the genus (generotype) and the type species of the assemblage. So that, one other species ought to be retained for the whole assemblage (see Broin 1977) and this might be the holotype shell of Eusarkia rotundiformis Bergounioux, 1952 although it does not present all the diagnostic characters of the species. In these Tunisian specimens, the polygons are protruding, when they are not mostly eroded as in Eusarkia rotundiformis, and they form, as in Taphrosphys sulcatus, a better defined net of polygons than in S. ragei n. gen., n. sp. During the Maastrichtian of other countries, some isolated fragmentary specimens individually preserve diagnostic features of T. sulcatus: 1) xiphiplastral shape and scars; 2) similar anterior lobe scute sulci; 3) similar anterior elongation and rounded anterior shape; 4) characteristic ventral scars on the costal 1 of the hyoplastral buttress and ribs 1 and 2; and 5) short costals, posterior to the first one. They have a similar fine and regular protruding ornamentation as in T. sulcatus; the small polygons (which are elongated or not according to their place on the plates) are well united in the same net as in T. sulcatus, T. congolensis and the Tunisian group, contrarily to the $S$. ragei $i$. gen., n. sp. ornamentation. These Maastrichtian remains are attributed to T. sulcatus in phosphates of Syria, at Charquieh (Bardet et al. 2000: figs 7a, b, c) and to Taphrosphys cf. sulcatus in Egypt, at Ammonite Hills, close to the Dakhla oasis (Lapparent de Broin \& Werner 1998: fig. 3 [3]). Two species of Taphrosphys from the Maastrichtian of Mont-Aimé (France) and Eocene of Peru (respectively) have been separated from the genus and placed in two new genera 
by Pérez-García (2018b) and Pérez-García et al. (2018): they share Taphrosphys principal diagnostic features (decoration, plastral scute pattern and various others). The Maastrichtian Syrian and Egyptian shell elements which are the closest to T. sulcatus among the Taphrosphyini have not been integrated in these works, no more than new Maastrichtian taphrosphyine carapaces of Phosphates of Morocco (Bardet et al. 2018) (OCP collections observed at Khouribga): this Maastrichtian presence shows that the tribe Taphrosphyini is recorded by Taphrosphys or cf. Taphrosphys in Africa and Syria and by a close taxon in France as early as the Maastrichtian. Thus, during the Maastrichtian, the tribe occupyied a widespread distribution along the northern platform coast, Neotethyan borders and appendices, including its presence as northern as at the Mont-Aimé (France) and western in Morocco. The tribe is well defined as a derived monophyletic group before its Paleocene radiation, before the derivation of the nigeremydine Azzabaremys-Acleistochelys clade and before the presence of $S$. ragei n. gen., n. sp. in Pakistan, which does not appear to be associated with the taphrosphyine tribe.

Comparison of the shape of the carapace of Sindhochelys ragei n. gen., n. sp. with Taphrosphyini

Although the ornamentation shows some similarities, the comparison of the shell shape of Taphrosphys sulcatus with that of Sindhochelys ragei n. gen., n. sp. does not support a close relationship between them. The carapace may not be as important for its length as that of $S$. ragei n. gen., n. sp., even taking into account a possible relative difference of width or length due to the sexual dimorphism: the shape variability in T. sulcatus is shown by the figures of Hay (1908) as limited in one specific frame. The carapace of T. sulcatus is reconstructed in Hay (1908) and Gaffney (1975) by different contours and some of the Gaffney's figures need a revision. As seen in Figure 9E and in figures of Hay (1908), even in the more anteriorly protruded carapace, the anterior border is not the most protruded at the nuchal alone as figured in two reconstructions of Gaffney (1975: figs 1 and 5): these two figures give the species a much ovoid shape; but the carapace anterior border is straight at the medial part of the peripherals 1 beside at the nuchal border. It is the same even in the more taphrosphyine protruded carapaces, those of the species of the Eusarkia-"Gafsachelys" group (see "Gafsachelys neurriregularis" Bergounioux, 1952 and "G. moularensis" Bergounioux, 1956). In T. sulcatus, laterally to this anterior straight border, the borders diverge posteriorly as figured in Gaffney (1975: fig. 5). From all the partial specimens figured in Hay (1908), the anterior curve of the contour is too much rounded in the two reconstitutions of Gaffney (1975: figs 1, 5). As a whole, the carapace of T. sulcatus is overall ovoid, although not completely rounded at the anterior medial part, with the posterior widening at the peripherals 7-8 (presenting lateral borders parallel on that short length), followed by a progressive posterior curved protrusion, towards a median protrusion that is maximal at the level of the pygal, as presented in Gaffney (1975: fig. 5); but the carapace does not present a posterior trapeze with rounded angle as in Gaffney (1975: figs 3 and 4): his best reconstruction ought to be his figure 5 , adding a correction for a narrow straight border at the nuchal and medial part of the adjacent peripherals 1 . Endly, the best precise carapace representation of T. sulcatus appears in the figure of the type of "Taphrosphys longinuchus" Cope, 1870, in Hay (1908: fig. 101). As anteriorly described in this way, with its posteriorly positioned maximal width and with the not in $\mathrm{V}$ pointed posterior border, the carapace is clearly different from that of $S$. ragei n. gen., n. sp.. The shape of the carapace of T. congolensis, as reconstructed by Pérez-García et al. (2018), appears as morphologically close to that of $T$. sulcatus, differing by the small nuchal notch of the former, and knowing the plastra are globally similar (Gaffney 1975; Wood 1975; Pérez-García et al. (2018).

The differences between Taphrosphys and Sindhochelys ragei n. gen., n. sp. are also those that differentiate the latter from Carteremys leithii. In C. leithii, the anterior part of the carapace is not as elongate as in T. sulcatus and not as wide as $S$. ragei n. gen., n. sp., and C. leithii does not appear as being a taphrosphyine (see Lapparent de Broin \& Guntupalli 2020). In other Taphrosphyini species, the carapace is not enough complete but when preserved, the shape is likewise mostly ovoid as that of T. sulcatus. Among the Tunisian specimens from Gafsa, the best specimens, with a nearly complete shape, are "Gafsachelys moularensis" and the similar "G. neurriregularis" in Bergounioux (1956: pl. 10). In these individuals, the anterior protrusion is preserved: it is specifically maximal in relation to other taphrosphyines, with a narrower nuchal-peripheral 1 part - anterior straight border and they have less medially inclined and longer lateral borders, framing a very elongated medial part; so that the carapace looks more strictly "ovoid," being more protruded than in T. sulcatus, and anyway far from the contour of $S$. ragei n. gen., n. sp. However, Gafsa form shape remains in the general frame of that of T. sulcatus.

\section{Comparison of the plastral shape of Sindhochelys ragei n. gen., n. sp. with Taphrosphyini}

In addition to the decoration, the comparison of the scute pattern of the anterior plastral lobe shows that all members of Taphrosphyini have the generalized anterior lobe scute pattern reconstructed for Sindhochelys (Figs 3B; 4B), i.e. that of a wide and long intergular separating the humerals and contacting the pectorals, and, further, the humeropectoral sulcus is not anterior to the epihyoplastral suture in Taphrosphyini and S. ragei n. gen., n. sp. The complete plastron of T. sulcatus is not fully preserved on each specimen, and the reconstruction (Gaffney 1975) did not include the variabilities presented by other New Jersey specimens in Hay (1908): the position of the humeropectoral varies from linked to the epihyoplastral suture in "T. molops" (type AMNH 1472), slightly more than in $S$. ragei n. gen., n. sp., to far posterior in "T. leslianus" (AMNH 1471, a specimen with the epiplastra and a left hyoplastron but without the entoplastron). Thus, this sulcus is never anterior to the epihyoplastral suture as in other taphrosphyines (Montenat \& Merle 2018: fig. 164B1; Pérez-García et al. 2018). The entoplastron is figured by Hay (1908) as variably long posterior to this suture. At the differ- 
ence from $S$. ragei n. gen., n. sp., the intergular is pointed in a medial V, at the junction with the pectorals (as in Elochelys perfecta) in "T. molops" figured specimen of Hay (1908); but the V is variable in length in other "species", where the sulcus is, nevertheless, not as transversal as in $S$. ragei n. gen., n. sp. and in some Carteremys group members (Lapparent de Broin et al. 2009; Lapparent de Broin \& Guntupalli 2020). The scute plastral pattern of T. sulcatus is the same in other Taphrosphyini, including the Eusarkia-"Gafsachelys" group: the sulci are not correctly figured or visible in all drawings and photographs of Bergounioux $(1952 ; 1956)$, but the $\mathrm{V}$ is visible on "Gafsachelys neurriregularis" (Bergounioux 1956: pl. 123, fig. 1), and the holotype of Eusarkia rotundiformis, with the $\mathrm{V}$ pointed intergular.

The plastron of Sindhochelys ragei n. gen., n. sp. has not only a similar generalized scute pattern (although with the above exposed differences concerning the sulcus between humerals, intergular and pectorals precise position), but it has another similarity with $T$. sulcatus by the trapeze shape of the anterior lobe, although it is wider in $S$. ragei n. gen., n. sp. In fact, as $S$. ragei n. gen., n. sp. has its own proportions, beside the "species of Hay, 1908" assembled in T. sulcatus, each other taphrosphyine species has its own proportions in the width of the lobes, shape of the lobes, degree of convergence of the lateral borders, proximity of the abdominofemoral sulcus with the hyohypoplastral suture, width of the posterior lobe at abdominofemoral sulcus in relation to the anterior lobe at the bottom of the axillary notches, and degree of rounding of the posterior lobe posteriorly to this sulcus: because of individual small variations, with only one specimen by species, it is difficult to define the characteristic proportions of each species in a defined specific frame. For the posterior lobe shape, two taphrosphyines (each one preserved by one specimen) share with $S$. ragei n. gen., n. sp. (one specimen) a posterior lobe with few or barely rounded lateral borders: T. congolensis and Eotaphrosphys ambiguus (Gaudry, 1890) (Broin 1977; Montenat \& Merle 2018; Pérez-García 2018b; Pérez-García et al. 2018). T. sulcatus, as it is reconstructed in Gaffney (1975), on the base of the syntype xiphiplastron and on the other New Jersey fragmentary specimens (Hay1908), has a posterior lobe anal part with a slightly concave lateral border and it is more or less narrowed: that has a possible sexual variability. Motelomama olssini (Schmidt, 1931) from the Eocene of Peru, and the Ypresian Eusarkia- "Gafsachelys" group from Gafsa (Bergounioux 1952, 1956), share a wider posterior lobe at its base and also a narrowed rounded anal part. As far as S. ragei n. gen., n. sp. is concerned, the posterior lobe has a weak progressive convexity of the lateral borders, which is similar to that of Eotaphrosphys ambiguus: this is a less derived feature than a wide and more rounded lobe border and a more narrowed anal part, as present in the other above cited species. In a cladistic analysis, it simply represents a primitive character and not a derived shared character by $S$. ragei n. gen., n. sp. and T. sulcatus. The taphrosphyine anal notch is differently deep, rounded or straight and wide or narrow, often concave with pointed extremities, varying in each species: it varies from primitively wide and very short in E. ambiguus (Montenat \& Merle 2018: fig. 164C), slightly more concave (and variably wide) in T. sulcatus and up to narrower and longer in M. olssoni. The anal notch of $S$. ragei n. gen., n. sp. is incomplete: from the remaining border, it was probably morphologically close to that of E. ambiguus in length and width, possibly not concave with not pointed ends, and then probably relatively primitive among bothremydids. The inner face not being visible in $S$. ragei n. gen., n. sp., it cannot be appreciated if there was a taphrosphyine ischiatic scar with its characteristic rounded spot; the extremity of the plastron is broken at the ischiatic suture, and, looking in posterior view, it does not seem the spot was present.

Finally, although similarities with bothremydid species, which share the same "generalized anterior lobe scute pattern" with a weak (Elochelys perfecta) to more strongly protruded (Carteremys leithii group, Taphrosphyini) decoration or without a decoration ("Carteremys" pisdurensis), Sindhochelys is different from all bothremydids together by the shape of the shell, its decoration and its unique scute/suture relations, particularly in the anterior lobe scute pattern.

Gen. et sp. indet.

(Fig. 10)

EXAMINED MATERIAL. - Fragment of a carapace constituted of two right peripherals with adjacent peripherals and costal parts, CPAG-RANKT-V-4.

LOCALITY. - Lower part of the Khadro Formation of the Ranikot Group, early Paleocene, locality K18-12, in the proximity of Ranikot Fort, Jamshoro District, Sindh Province, Southern Pakistan (Fig. 1).

\section{DESCRIPTION AND COMPARISONS}

The specimen $(17 \mathrm{~cm}$ long $\times 10 \mathrm{~cm}$ wide $)$ includes a right bridge portion of carapace with the posterior part of the peripheral 5 , the complete peripherals 6 and 7 , with a small part of the peripheral 8 , sutured to the lateral end of the costals 3 (part), 4 (complete extremity) and 8 (minimal part). In dorsal view (Fig. 10B, C), the peripherals (complete $6^{\text {th }}$ and 7 th) are wide and display an incurved surface. The free border is thick but neither rounded nor acute. In ventral view (Fig. 10A), the posterior extremity of the bridge is positioned at first third of the $7^{\text {th }}$ peripheral. The sutured border of the plates with the plastron is weakly indented to receive the corresponding weak indentations of the hypoplastron. The fragment was colonized by a perforating animal, such as the pholad bivalve, which nested forming rounded cavities. That occurred once the carapace was dislocated in the marine-littoral water ground, because the cavities are distributed as well on the external face, on the periphero-hypoplastral suture and in the inner bridge cavity, being of various sizes.

The fragment is noticeable by its ornamentation, which does not substantially differ from that of $S$. ragei n. gen., n. sp., being made of wide protruding polygons (Fig. 10C) 

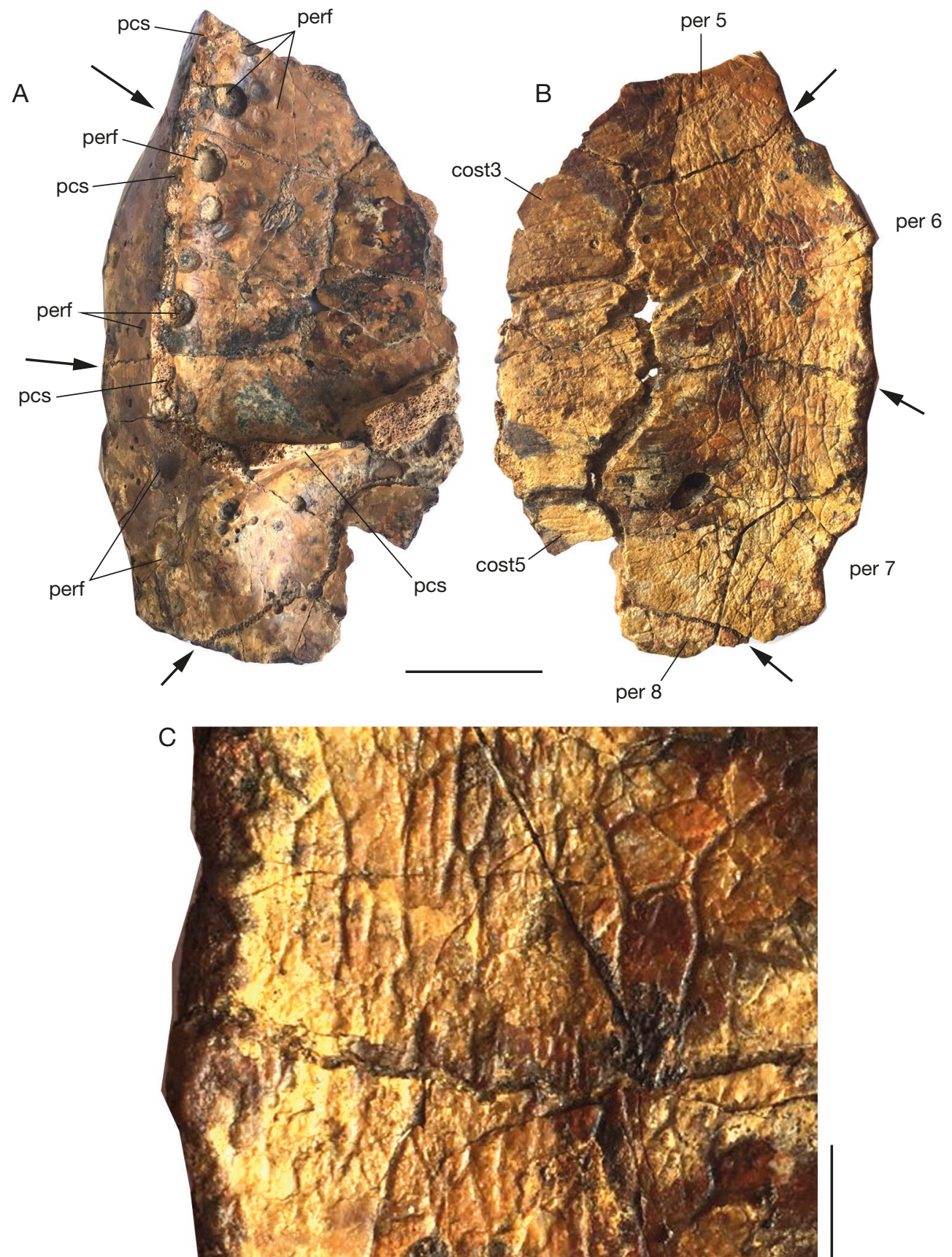

FIG. 10. - Fragmentary part of a carapace of an undetermined Bothremydidae, from the Paleocene of Ranikot, locality K18-12, CPAG-RANKT-V4, Southern Pakistan: A, B, ventral and dorsal views; C, detail of the dorsal decoration. Abbreviations: cost3, costal 3; cost5, costal 5; pcs, suture of the peripheral border with the border of plastral processes; per 5-8, peripherals 5, 6, 7, 8; perf, pholad perforations. Scale bars: A, B, $4 \mathrm{~cm}$; C, $1 \mathrm{~cm}$.

but which are more marked. The polygons are very elongated and well defined and as elongated as in some plates of S. ragei n. gen., n. sp., (Fig. 8C, E), but more protruding, perhaps because of a better preservation at this location. The only certitude is that it does not correspond to any other decorated bothremydid examined above by comparison with Sindhochelys. Although similar to Sindhochelys by the marked decoration and different from taphrosphyines and other examined bothremydids from France and India, the fragment remains undetermined.

\section{DISCUSSION AND CONCLUSIONS}

\section{SYSTEMATIC AFFINITIES}

Within Bothremydidae, Sindhochelys ragei n. gen., n. sp. appears as a new littoral form. At first instance, it seems to share the decoration and plastral scute pattern with Tahrosphyini. The study shows that these characters differ in the way they are made: among the species sharing the generalized scute plastral pattern and a marked decoration, $S$. ragei $n$. gen., n. sp. is unique in the details of these elements besides it is unique in the shape 
of its carapace and the contour of the constituting elements. Thus, it is different from Taphrosphyini (sensu nostro), as well as from Carteremys lethii group from India and from Elochelys perfecta from France which are not closely related taxa.

Sindhochelys ragei $\mathrm{n}$. gen., n. sp. cannot be referred to any of the few bothremydid forms known by their shell from Paleocene times: - either decorated: Taphrosphys sulcatus, T. congolensis (the other taphrosphyine Danian forms not being known by their shell [Gaffney et al. 2006]); - or not decorated: Puentemys from Colombia, the undefined form from Maria Farinha Fm. of Pernambuco, Brazil, DNPM (observed by Campos de Almeida \& Broin [1981]) and "Podocnemis" indica Lydekker, 1885 from the Paleocene beds of Nila (Salt Range, Pakistan). In addition to $S$. ragei n. gen., n. sp., the latter is the only known other Paleocene Pakistani bothremydid, and both are closer in age. But this species is of an undetermined genus, known only by a drawing of a dorsal carapace, without ornamentation, carinated on the figure (although indicated as not carinated in Lydekker's text, being perhaps just tectiform), narrow and oval, not at all similar to that of $S$. ragei $n$. gen., n. sp., and thus indicates no close relationship between the two. Moreover, S. ragei n. gen., n. sp. cannot be referred to any Cretaceous form defined by its shell and/or skull. In the absence of skull or shell in all the species, the phylogenetic affinities of $S$. ragei n. gen., n. sp. cannot yet be defined.

Large shells of bothremydids have been reported from several Maastrichtian stratigraphic intervals of the Mt Indamane Mt In Tahout area of the Iullemmeden basin (Greigert 1966; Moody \& Sutcliffe 1991; Lapparent de Broin et al. 2020), Niger. The decoration and plastral pattern of these undescribed shells are unknown. Ilatardia Pérez-García, 2019b, was described by a skull alone in another Maastrichtian layer of the same basin, at Ilatarda. In absence of its shell, any comparison with $S$. ragei $n$. gen., n. sp. is possible. The skull of Ilatardia is very close to that of Nigeremys and we refer Ilatardia to the Nigeremydini (sensu Lapparent de Broin \& Guntupalli 2020). Since the rare shells known (complete or fragmentary) in this tribe (Lapparent de Broin \& Werner 1998; Moody \& Sutcliffe 1991; O’Leary et al. 2019) are not decorated by raised well protruding polygons, it is probable that Ilatardia is not related to $S$. ragei n. gen., n. sp. (Lapparent de Broin et al. 2020). Other decorated forms existed in the Iullemmeden basin, but they are undetermined and too poorly known to be fruitfully compared with $S$. ragei n. gen., n. sp. (see below).

\section{PALEOGEOGRAPHIC CONSIDERATIONS}

During the early Paleocene, the Ranikot area, as part of the Indian Subcontinent, was separated from Madagascar and from Africa, but closer to the Madagascan coasts than to the northern part of Africa where bothremydids are known at that time. The Bothremydidae are a Gondwanan taxon, the earliest representatives of which are from the early Cretaceous of northern Gondwana (Broin 1988). There are two main paleobiogeographic hypotheses to explain the presence of bothremydids in Pakistan. Sindhochelys ragei n. gen., n. sp. and "Podocnemis indica" may have evolved from forms which inhabited eastern Gondwana before the Gondwana breakup between the Indian Subcontinent and Madagascar, during the early late Cretaceous, but their shells are unknown. Undecorated and decorated bothremydids are known in the Albian to Maastrichtian of India (Ayyasami \& Das 1990; Lapparent de Broin \& Guntupalli 2020) and Madagascar (Lapparent de Broin \& Werner 1998; Lapparent de Broin 2000; Gaffney et al. 2006). Carteremys leithii from the Maastrichtian of India is the only decorated form but we demonstrated previously that it is not closely related to $S$. ragei n. gen., n. sp. An undetermined shell (preserved with some other poor elements in the MNHN.F collections) has been reported in the Cenomanian of Madagascar, but it is not decorated as in S. ragei n. gen., n. sp. (Lapparent de Broin \& Werner 1998). Other forms are defined from the Cenomanian of Madagascar, but their shell is unknown (Gaffney et al. 2006).

Another hypothesis is that African bothremydids dispersed across the Neotethys to the Indian Subcontinent as it is attested for adapisoriculid mammals (Prasad et al. 2010). The age of this dispersal event(s) remains contentious, but it is worth noting that bothremydids are coastal turtles without the paddles of marine turtles, and their dispersion depends of favorable currents, and only between close areas and along the coasts. During the late Maastrichtian to early Paleocene, no bothremydid is known in the eastern part of Africa, but the family is well diversified in the northern part and in the surrounding Neotethysian areas, as early as Cenomanian. A current of northwestern-southeastern direction initiated in Africa or a relay between continents by a volcanic archipelago may have possibly favored the dispersal of littoral bothremydids during the late Cretaceous or the earliest Paleocene. Decorated bothremydids occurred in the Iullemmeden basin (Niger), which was situated on the western border of the Trans-Saharan seaway and connected to the Neotethys. Besides other well-identified tribes including decorated taphrosphyines, and undecorated Nigeremydini and Bothremydini, Bothremydidae indet. are reported from the Maastrichtian Ammonite Hills Formation (Egypt) (Lapparent de Broin \& Werner 1998; Lapparent de Broin 2000) but they are not decorated. In contrast, isolated plates (MNHN.F 1967.27 coll.) of undefined bothremydids from the Iullemmeden of Niger, display a rather similar decoration to that of $S$. ragei n. gen., n. sp. These undefined bothremydids were recovered from the "papyraceous shales bed" of the Mt In Tahout area, which is considered Thanetian in age according to the oil-geologists who discovered the fossils (Lapparent de Broin et al. 2020), and they correspond to the Kao Member of the Garadoua Formation, which is exposed in the Iullemmeden basin (Dikouma et al. 1994). Thus, they are probably younger than $S$. ragei n. gen., n. sp. from Ranikot. Another decorated peripheral of a bothremydid from Mt Indamane (of the same basin) is figured (Michaut 2002, 2007). This specimen referred as to "Testudines" by Michaut (2002) is about the size of S. ragei n. gen., n. sp., and its decoration with wide protruding polygons is similar. The specimen might come from the same Paleocene level as the elements of the neighboring Mt In Tahount level (Lapparent de Broin et al. 2020). Although these fossils are still 
insufficient, their presence suggests that dispersal corridors might have occurred along the Trans-Saharan seaway, thus possibly connecting biogeographically Eastern Africa and India during the Maastrichtian or the Paleocene.

The occurrences of Sindhochelys ragei n. gen., n. sp. and "Podocnemis" indica indicate that the bothremydids were relatively diversified in the western margin of the Indian Subcontinent during the Paleocene. During the early Eocene, pleurodirans are represented by undetermined Pelomedusoides in India (Smith et al. 2016) and perhaps also in the Eocene of Pakistan (Broin 1987).

\section{Acknowledgements}

We thank Parveen Usmani, and all the colleagues from the University of Sindh for their enthusiasm, expertise, and logistic support. We are thankful to the former French Consuls Pierre Seillan and Christian Ramage, and to the French Alliance in Karachi for their support. The French Embassy in Islamabad, in particular the Counsellor for Cooperation and Cultural Affairs Martine Herlem-Hamidi, Campus-France, and the MNHN Paris financially supported study stays of Rafiq A. Lashari at MNHN, Paris. At MNHN, we thank Philippe Richir and Yohan Després who prepared the specimen, Lilian Cazes for assistance in the photographic work, and Marie-Astrid Angel for assistance in bibliography. The fieldwork was funded by the Department for Pure and Applied Geology (University of Sindh), the ATM MNHN "Biodiversité actuelle et fossile", the programme INTERRVIE CNRS-INSU, and the ANR-ERC PALASIAFRICA Program (ANR-08-JCJC-0017). For the access to comparative material, we thank Daniel Baudet (MRAC, Tervuren), Eugene S. Gaffney (AMNH, New York), Diogenes Campos de Almeida (DNPM, Rio de Janeiro), Vincent Poncet (MHNM, Marseille), François Dusoulier (MNHN, Paris), and Adàn Pérez-García (Madrid). We warmly thank the reviewers Massimo Delfino and Prasad Guntupalli for their pertinent remarks. This is a contribution to the 'Ranikot Project, continental Cenozoic beds of Sindh (Pakistan)'. The MNHN gives access to the collections in the framework of the RECOLNAT national Research Infrastructure.

\section{REFERENCES}

Agheem M. H., Solangi S. H., Hakro A. A., Mastoi A. S. \& SIDDIQUi I. 2011. - Major element geochemistry of basalt exposed at Ranikot area, lower Indus basin, Pakistan. Journal of Himalayan Earth Sciences 44: 33-43.

Antunes M. T. \& Broin F. De 1988. — Le Crétacé terminal de Beira Litoral, Portugal: remarques stratigraphiques et écologiques; étude complémentaire de Rosasia soutoi (Chelonii, Bothremydidae). Ciências da Terra (Universidade Nova de Lisboa) 9: 153-200.

AYYASAMI K. \& DAS I. 1990. - Unusual preservation of a Cretaceous turtle fossil. Journal of the Geological Society of India 36: 519-522.

Bardet N., Cappetta H., Pereda-Suberbiola X., Mouty M., Ai Maleh A. K., Ahmad A., Khrata M. O. \& Gannoum. 2000. The marine vertebrate faunas from the Late Cretaceous of Syria. Geological Magazine 137 (3): 269-290. https://doi.org/10.1017/ S0016756800003988
Bardet N. E., Gheerbrant E., Noubhani A., Cappetta H., Jouve S., Bourdon E., Pereda Suberbiola X., Jalil N. E., Vincent P., Houssaye A., Sole F., Elhoussaini Darif K., Adnet S., Rage J.-Cl., Lapparent de Broin F. DE, Sudre J., Bouya B., Amaghzaz M. \& Meslouhet Al S. 2018. — Les Vertébrés des Phosphates crétacés-paléogènes (70.6-46.6 Ma) du Maroc, in Zounri S. (ed.), La Paléontologie des Vertébrés du Maroc. Mémoires de la Société géologique de France 180: 355-454.

Bergounioux F. M. 1952. - Les Chéloniens fossiles de Gafsa, in Arambourg C. \& Signeux J., Les Vertébrés fossiles des gisements de Phosphates (Maroc-Algérie-Tunisie). Notes et Mémoires du Service géologique du Maroc 92, appendix: 377-396.

BergouniouX F. M. 1956. - Les reptiles fossiles des dépôts phosphatés sud tunisiens. Annales des Mines et de la Géologie 15: 1-105.

Bergounioux F. M. \& Crouzel F. 1968. — Deux tortues fossiles d'Afrique. Bulletin de la Société d'Histoire naturelle de Toulouse 104 (2): 179-186. https://gallica.bnf.fr/ark:/12148/bpt6k6556498r/ f185.image

BLANFORD W. T. 1876. — On the geology of Sind. Indian Geological Survey Records 9: 8-22.

Blanford W. T. 1879. - The geology of Sindh. Memoirs of the Geological Survey of India 18: 1-196.

Broin F. De 1977. - Contribution à l'étude des Chéloniens. Chéloniens continentaux du Crétacé et du Tertiaire de France. Muséum national d'Histoire naturelle, Paris, 366 p. (Mémoires du Muséum national d'Histoire naturelle, sér. C, Sciences de la Terre; Vol. 38). https://www.biodiversitylibrary.org/page/58317560

BROIN F. DE 1980. — Les Tortues de Gadoufaoua (Aptien du Niger): aperçu sur la paléogéographie des Pelomedusidae (Pleurodira). Mémoires de la Société géologique de France, N.S., 139: 39-46.

BROIN F. DE 1987. — Lower Vertebrates from the early-middle Eocene Kuldana Formation of Kohat (Pakistan). Chelonia. Contributions from the Museum of Paleontology, University of Michigan 27 (7): 169-185.

BROIN F. DE 1988. — Les Tortues et le Gondwana. Examen des rapports entre le fractionnement du Gondawana et la dispersion géographique des Tortues pleurodires à partir du Crétacé. Studia Geologica Salmanticensia, Studia Palaeocheloniologica 2 (5): 103-142.

Cadena E. A., Ksepka D. T., Jaramillo C. A. \& Bloch J. I. 2012. - New pelomedusoid turtles from the late Palaeocene Cerrejón Formation of Colombia and their implications for phylogeny and body size evolution. Journal of Systematic Palaeontology 10:313-331. https://doi.org/10.1080/14772019.2011.569031

Campos de Almeida D. \& BROIN F. DE 1981. - Tartarugas fosseis do Brasil. Anais de Academia Brasileira de Ciências, Resumos de comunicaçóes 53 (1): 210-211

CARrington Da Costa J. 1940. - Um novo Quelónio fossil. Comunicaçãos dos Serviços Geológicos de Portugal 21: 107-125.

CARTER H. J. 1852. - Geology of the Island of Bombay. Journal of the Bombay branch of the Royal Asiatic Society 21: 161-215.

Cheema M. R., Raza S. M. \& Ahmad H. 1977. - Cenozoic, in SHAH S. M. I. (ed.), Stratigraphy of Pakistan. Memoirs of the Geological Survey of Pakistan, Vol. 12: 56-98.

Cope E. D. 1870. - The fossil of New Jersey. Part II. The American Naturalist 3: 84-91. https://doi.org/10.1086/270371

Dikouma M., Lang J., Laurin B., Pascal A. \& Salard-CheboldaefF M. 1994. - Biostratigraphy of some Maastrichtian and Paleocene formations in the Iullemmeden Basin (southern Niger). Neues Jahrbuch fur Geologie und Palaontologie, Abhandlungen 193: 55-79.

Douvillé H. 1928. - Les couches à Cardita Beaumonti dans le Sind. Memoirs of the Geological Survey of India - Palaeontologica Indica 10: 1-73.

EAMES F. E. 1952. - A contribution to the study of the Eocene in western Pakistan and western India: D. Discussion of the faunas of certain standard sections, and their bearing on the classification and correlation of the Eocene in western Pakistan and western India. Quarterly Journal of the Geological Society of London 107: 173-196. https://doi.org/10.1144/GSL.JGS.1951.107.01-04.08 
Ferreira G. S., Bandyopadhyay S. \& Joyce W. G. 2018. — A taxonomic reassessment of Piramys auffenbergi, a neglected turtle from the late Miocene of Piram Island, Gujarat, India. PeerJ 6: e5938. https://doi.org/10.7717/peerj.5938

GAFFNEY E. S. 1975. - A revision of the side-necked turtle Taphrosphys sulcatus (Leidy) from the Cretaceous of New Jersey. American Museum Novitates 2571: 1-24. http://hdl.handle.net/2246/5459

Gaffney E. S. \& Krause D. W. 2011. — Sokatra, a New SideNecked Turtle (Late Cretaceous, Madagascar) and the Diversification of the Main Groups of Pelomedusoides. American Museum Novitates 3728: 1-28. https://doi.org/10.1206/3728.2

GafFney E. S. \& ZANGerL R. 1968. - A Revision of the Chelonian Genus Bothremys (Pleurodira: Pelomedusidae). Fieldiana Geology 16 (7): 193-239. https://www.biodiversitylibrary.org/ page/4254119

Gaffney E. S., Campos de Almeida \& Hirayama R. 2001a. Cearachelys, a new side-necked turtle (Pelomedusoides: Bothremydidae) from the Early Cretaceous of Brazil. American Museum Novitates 3319: 1-20. https://doi.org/dvbsbx

Gaffney E. S., Chatterjee S. \& Rudra D. K. 2001b. - Kurmademys, a New Side-Necked Turtle (Pelomedusoides: Bothremydidae) from the Late Cretaceous of India. American Museum Novitates 3321: 1-16. https://doi.org/fmbw4g

Gaffney E. S., Moody R. T. J. \& Walker C. A. 2001c. Azabbaremys, a new Side-Necked Turtle (Pelomedusoides: Bothremydidae) from the Paleocene of Mali. American Museum Novitates 3320: 1-16. https://doi.org/dp6nht

Gaffney E. S., Tong H. \& Meylan P. A. 2002. - Galianemys, a new side-necked turtle (Pelomedusoides: Bothremydidae) from the Late Cretaceous of Morocco. American Museum Novitates 3379: 1-20. https://doi.org/bdq6kd

Gaffney E. S., Sahni A., Schleich H., Singh S. D. \& SrivASTAVA R. 2003. - Sankuchemys, a New Side-Necked Turtle (Pelomedusoides: Bothremydidae) from the Late Cretaceous of India. American Museum Novitates, 3405: 1-10. https://www. biodiversitylibrary.org/page/60862403

Gaffney E. S., TONG H. \& Meylan P. A. 2006. — Evolution of the side-necked turtles: the families Bothremydidae, Euraxemydidae, and Araripemydidae. Bulletin of the American Museum of Natural History 300: 1-700. https://doi.org/dgxpvn

GAFFnEy E. S., RoberTs E., SisSOKO F., BOUARÉ M., TAPANILA L. \& O'Leary M. 2007. - Acleistochelys, a New Side-Necked Turtle (Pelomedusoides: Bothremydidae) from the Paleocene of Mali. American Museum Novitates 3549: 1-24. https://doi.org/fnhdj7

Gaffney E. S., Krause D. W. \& Zalmout I. S. 2009. - Kinkonychelys, A New Side-Necked Turtle (Pelomedusoides: Bothremydidae) from the Late Cretaceous of Madagascar. American Museum Novitates 3662: 1-25. https://doi.org/10.1206/672.1

Gaffney E. S., Meylan P. A., Wood R. G., Simons E. \& Campos DE AlmeIDA D. 2011. - Evolution of the side-necked turtles: the family Podocnemididae. Bulletin of the American Museum Natural History 350: 1-237. https://doi.org/10.1206/350.1

GAUDRY A. 1890. - Les enchaînements du monde animal dans les temps géologiques. Fossiles secondaires. F. Savy, Paris, 323 p. https:// gallica.bnf.fr/ark:/12148/bpt6k62124748

GREIGERT J. 1966. - Description des formations crétacées et tertiaires du bassin des Iullemmeden. Carte géologique "Le Bassin des Iullemmeden». Direction des Mines et de la Géologie, République du Niger, BRGM, 2: 234 p.

HAAs G. 1978a. - A Cretaceous Pleurodire Turtle from the Surroundings of Jerusalem. Israel Journal of Zoology 27: 20-33.

HaAs G. 1978b. - A new turtle of the genus Podocnemis from the lower Cenomanian of 'Ein Yabrud. Israel Journal of Zoology 27: 169-175.

HalsteAd L. B. 1979. - A Taxonomic Note on New Fossil Turtles. Nigerian Field, The International Field Studies. Journal of West Africa, Mon. 1, Suppl. to 44, Arthurs Press Ltd, Woodchester, Stroud, Glos: 48-49.
Haughton S. H. 1928. - On some reptilian remains from the dinosaur beds of Nyasaland. Transactions of the Royal Society of. South Africa 16: 67-5.

HAY O. P. 1908. - The Fossil Turtles of North America. Publications of the Carnegie Institution 75: 1-568. https://doi.org/10.5962/ bhl.title. 12500

JAIN S. L. 1977. — A new fossil Pelomedusid Turtle from the Upper Cretaceous Pisdura sediments, Central India. Journal of the Palaeontological Society of India 20: 360-365.

JAIN S. L. 1986. — New Pelomedusid turtle (Pleurodira: Chelonia) remains from Lameta Formation (Maastrichtian) at Dongargaon, Central India, and a review of Pelomedusids from India. Journal of the Palaeontological Society of India 31: 63-75.

JoyCE W. G., Lyson T. R. \& KirKLAND J. I. 2016. — An early bothremydid (Testudines, Pleurodira) from the Late Cretaceous (Cenomanian) of Utah, North America. PeerJ 4: e2502 https:// doi.org/10.7717/peerj. 2502

LAPPARENT DE BROIN F. DE 2000. - African chelonians from the Jurassic to the Present. A preliminary catalog of the African fossil chelonians. Palaeontologia Africana 36: 43-82.

LAPPARENT DE BROIN F. DE 2001. - The European turtle fauna from the Triassic to the Present. Dumerilia 4 (3): 155-216.

Lapparent de Broin F. DE, Chirio L. \& Bour R. 2020. — The oldest erymnochelyine turtle skull, Ragechelus sahelica n. gen., n. sp., from the Iullemmeden basin, Upper Cretaceous of Africa, and the associated fauna in its geographical and geological context, in Steyer J.-S., Augé M. L. \& Métais G. (eds), Memorial Jean-Claude Rage: A life of paleo-herpetologist. Geodiversitas 42 (25): 455-484. https://doi.org/10.5252/geodiversitas2020v42a25. http://geodiversitas.com/42/25

Lapparent de Broin F. De, Murelaga X., Perez-García A., Farres F. \& Altimiras J. 2018. - A new cheloniid turtle from the upper Eocene Ebro basin of the Osona county (Catalonia, Spain) in its Eocene faunistic context. Fossil Record 21: 237-284. Online supplement. https://doi.org/10.5194/fr-21-237-2018

Lapparent de Broin F. DE, Guntupalli V. R. Prasad, Bajpai S. \& Verma O. 2009. - Chelonian remains from the Upper Cretaceous Deccan Intertrappean Beds of peninsular India: review, new material and comparisons, in BRINKMAN D. (ed.), Gaffney Turtle Symposium (Drumheller, Alberta, 17-18 October 2009), Royal Tyrrell Museum. Abstracts: 95-97.

Lapparent de Broin F. DE \& Guntupalli V. R. PRAsad 2020. Chelonian Pelomedusoides remains from the Late Cretaceous of Upparhatti (Southwestern India): Systematics and Palaeobiogeographical implications, in GUNTUPALli V. R. PRASAD (ed.), Biological Consequences of Plate Tectonics. Vertebrate Paleobiology and Paleoanthropology. Springer Science \& Business Media Publishers: 123-180. https://doi.org/10.1007/978-3-030-49753-8_7 LAPPARENT dE BROIN F. DE \& WERNER C. 1998. — New late Cretaceous turtles from the Western Desert, Egypt. Annales de Paléontologie 84 (2): 131-214. https://doi.org/10.1016/S0753-3969(98)80005-0

LEIDY J. 1856. - Notices of remains of extinct turtles of New Jersey, collected by Prof. Cook, of the State Geological Survey, under the direction of Dr. W. Kitchell. Proceedings of the Academy of Natural Sciences of Philadelphia 8: 303-304. https://www.biodiversitylibrary.org/page/1935359

LEIDY J. 1865. - Cretaceous reptiles of the United States. Smithsonian Contributions to Knowledge 14 (6): 1-135. https://www. biodiversitylibrary.org/page/32533476

LYDEKKER R. A. 1885. - Eocene chelonians from the Salt-Range. Palaeontologia Indica 10 (4): 59-65.

Michaut M. 2002. — Faune et écosystème marin épicontinental, Crétacé terminal du bassin des Iullemmeden, Niger. Publication CD (norme ICZN 2000).

MichaUt M. 2007. — Étude de Kaosaurus spiniferus, un Sauropsida du Maastrichtien d'Afrique de l'ouest, découvert dans le bassin des Iullemmeden, Niger. 26 p. https://hal.archives-ouvertes.fr/ hal-00177285 
Montenat C. \& Merle D. (COORD.) 2018. - Stratotype Danien. Muséum national d'Histoire naturelle, Paris, Biotope, Mèze ; Brgm, Orléans, 480 p. (Patrimoine géologique ; 9).

Moody R. T. J. 1972. - The turtle fauna of the Eocene phosphates of Metlaoui, Tunisia. Proceedings of the Geological Association 83 (3): 327-336

Moody R. T. J. \& Sutcliffe P. J. C. 1991. - The Cretaceous deposits of the Iullemmeden Basin of Niger, central West Africa. Cretaceous Research 12: 137-157. https://doi.org/10.1016/ S0195-6671(05)80021-7

NAGAPPA Y. 1959. - Foraminiferal biostratigraphy of the Cretaceous-Eocene succession in the India-Pakistan-Burma region. Micropaleontology 5: 145-177. https://doi.org/10.2307/1484208

NopCSA F. 1931a. - Note préliminaire sur quelques tortues du Danien du Midi de la France. Annales du Musée d'Histoire naturelle de Marseille 22 (6): 1-4.

NopCSA F. 1931b. - Sur des nouveaux restes de Tortues du Danien du Midi de la France. Bulletin de la Société géologique de France S.5, 3-4: 223-235.

O’Leary M. A., Mamadou A., Bouaré L., Claeson K. M., Heilbronn K. Hill R. V., Mccartney J., Sessa J. A., Sissoko F., Tapanila L., Wheeler E. \& RoberTs E. M. 1919. — Stratigraphy and Paleobiology of the Upper Cretaceous-Lower Paleogene sediments from the Trans-Saharan seaway in Mali. Bulletin of the American Museum of Natural History 436: 1-183. https:// doi.org/10.1206/0003-0090.436.1.1

PÉREZ-GARCÍA A. 2016. - A new turtle taxon (Podocnemidoidea, Bothremydidae) reveals the oldest known dispersal event of the crown Pleurodira from Gondwana to Laurasia. Journal of Systematic Palaeontology 15 (9): 1-23. https://doi.org/10.1080 /14772019.2016.1228549

PÉreZ-GARCÍA A. 2018a. - New information on the Cenomanian bothremydid turtle Algorachelus based on new, well-preserved material from Spain. Fossil Record 21: 119-135. https://doi. org/10.5194/fr-21-119-2018

PÉreZ-García A. 2018b. - New genera of Taphrosphyina (Pleurodira, Bothremydidae) for the French Maastrichtian 'Tretosternum' ambiguum and the Peruvian Ypresian 'Podocnemis' olssoni. Historical Biology 32 (4): 1-7. https://doi.org/10.1080/08912 963.2018.1506779

PéREZ-GARCía A. 2019a. - The African Aptian Francemys gadoufaouaensis gen. et sp. nov.: new data on the early diversification of Pelomedusoides (Testudines, Pleurodira) in northern Gondwana. Cretaceous Research 102: 112-126. https://doi.org/10.1016/j. cretres.2019.06.003

Pérez-García A. 2019b. - A new member of Taphrosphyini (Pleurodira, Bothremydidae) from the Maastrichtian of Niger. Journal of African Earth Sciences 158: 1-8. https://doi.org/10.1016/j. jafrearsci.2019.103548

Pérez-García A., Antunes M. T., Barroso-Barcenilla F., Callapez P. M., Segura M., Soares A. F. \& Torices A. 2017a. - A bothremydid from the middle Cenomanian of Portugal identified as one of the oldest pleurodiran turtles in Laurasia. Cretaceous Research 78: 61-70. https://doi.org/10.1016/j. cretres.2017.05.031

Perez-García A., Lapparent de Broin F. de \& Murelaga X. 2017b. - The Erymnochelys group of turtles (Pleurodira, Podocnemididae) in the Eocene of Europe: new taxa and paleobiogeographical implications. Palaeontologia Electronica 20 (1) 14A: 1-28. https://doi.org/10.26879/687
Pérez García A., Mees F. \& Smith T. 2018. — Shell anatomy of the African Paleocene bothremydid turtle Taphrosphys congolensis and systematic implications within Taphrosphyini. Historical Biology 32 (3): 376-385. https://doi.org/10.1080/08912963.2018.1497023

PRASAD K. N. 1974. - The vertebrate fauna from Piram Island, Gujarat, India. Memoires of the Geological Survey of India, New Series 41: 1-23.

Prasad G. V. R., Verma O., Gheerbrant E., Goswami A., KhoSla A., Parmar V. \& SAHni A. 2010. - First mammal evidence from the Late Cretaceous of India for biotic dispersal between India and Africa at the Kt transition. Comptes Rendus Palevol 9: 63-71. https://doi.org/10.1016/j.crpv.2009.12.003

Rage J.-C., Métais G., Bartolini A., Brohi I. A., Lashari R. A., Marivaux L., Merle D. \& Solangi S. H. 2014. - First report of the giant snake Gigantophis (Madtsoiidae) from the Paleocene of Pakistan: Paleobiogeographic implications. Geobios 47 (3): 147-153. https://doi.org/10.1016/j.geobios.2014.03.004

Roger J., Pickford M., Thomas H., Lapparent de Broin F. De, Tassy P., Van Neer W., Bourdillon-De-Grissac C. \& Al-BusAlDi S. 1994. - Découverte de vertébrés fossiles dans le Miocène de la région du Huqf au Sultanat d'Oman. Annales de Paléontologie 80 (4): 253-273.

Schmidt P. 1931. - A Fossil Turtle from Peru. Field Museum of Natural History, Geology, ser. 4, 8: 249-254.

SchmidT P. 1940. - A new Turtle of the Genus Podocnemis from the Cretaceous of Arkansas. Geological Service of the Field Museum of Natural History 8 (1): 1-12.

SHAH S. M. I. 2009. - Stratigraphy of Pakistan. Memoirs of the Geological Survey of Pakistan 22: 1-381.

SCHELLING 1999. - Frontal structural geometries and detachment tectonics of the northeastern Karachi arc, southern Kirthar Range, Pakistan. Geological Society of America, Special Paper 328: 287302. https://doi.org/10.1130/0-8137-2328-0.287

Smith T., Kumar K., Rana R. S., Folie A., Solé F., Noiret C., SteEman T., Sahni A. \& Rose K. D. 2016. - New early Eocene vertebrate assemblage from western India reveals a mixed fauna of European and Gondwana affinities. Geoscience Frontiers 7 (6): 969-1001. https://doi.org/10.1016/j.gsf.2016.05.001

TAQUeT P. 1976. - Géologie et paléontologie du gisement de Gadoufaoua (Aptien du Niger). Editions du Centre national de la recherche scientifique, Paris $191 \mathrm{p}$.

WalKer C. 1979. - New Turtles from the Cretaceous of Sokoto. The Nigerian Field, The International Field Studies, Journal of West Africa 1. (Suppl. to 44): 42-48.

Williams E. E. 1953. - Fossils and the distribution of chelyid turtles. 1. Hydraspis leithii (Carter) in the Eocene of India is a Pelomedusid. Breviora 1 (13): 1-8. https://www.biodiversitylibrary.org/page/3190040

Williams M. D. 1959. - Stratigraphy of the Lower Indus Basin, West Pakistan, in Proceedings of the $5^{\text {th }}$ World Petroleum Congress, New York. Section 1, paper 19: 377-394.

Wood R. C. 1970. - A review of the fossil Pelomedusidae (Testudines, Pleurodira) of Asia. Breviora 357: 1-24. https://www. biodiversitylibrary.org/page/4306436

Wood R. C. 1975. - Redescription of "Bantuchelys" congolensis, a fossil Pelomedusid Turtle from the Paleocene of Africa. Revue de Zoologie africaine 89 (1): 127-144.

ZANGERL R. 1948. - The Vertebrate Fauna of the Selma Formation of Alabama. Part II. The Pleurodiran Turtles. Fieldiana: Geology Memoirs 3 (2): 17-56. 